AUS DEM LEHRSTUHL FÜR UNFALLCHIRURGIE

PROF. DR. MED. MICHAEL NERLICH

DER FAKULTÄT FÜR MEDIZIN

DER UNIVERSITÄT REGENSBURG

Leukocyte-reduced platelet-rich plasma stimulates the in

vitro proliferation of adipose-tissue derived mesenchymal

stem cells depending on PDGF signaling

\author{
Inaugural - Dissertation \\ zur Erlangung des Doktorgrades \\ der Medizin \\ der \\ Fakultät für Medizin \\ der Universität Regensburg
}

vorgelegt von

Siegmund Lang 

AUS DER KLINIK UND POLIKLINIK FÜR UNFALLCHIRURGIE

(PROF. DR. MED. MICHAEL NERLICH)

DER FAKULTÄT FÜR MEDIZIN

DER UNIVERSITÄT REGENSBURG

Leukocyte-reduced platelet-rich plasma stimulates the in

vitro proliferation of adipose-tissue derived mesenchymal

stem cells depending on PDGF signaling

\author{
Inaugural - Dissertation \\ zur Erlangung des Doktorgrades \\ der Medizin \\ der \\ Fakultät für Medizin \\ der Universität Regensburg
}

vorgelegt von

Siegmund Lang 
Dekan:

1. Berichterstatter:

2. Berichterstatter:

Tag der mündlichen Prüfung:
Prof. Dr. Dr. Torsten E. Reichert PD Dr. med. Markus Loibl Prof. Dr. Dr. med. Lukas Prantl 23.04.2018 
1. Inhaltsverzeichnis

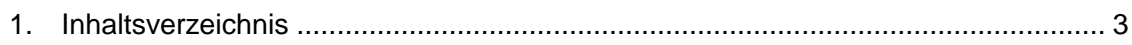

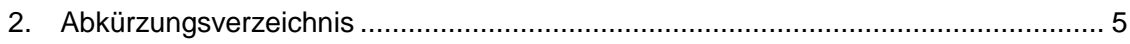

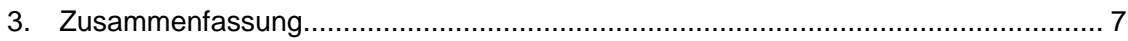

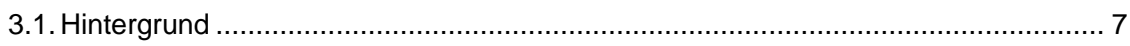

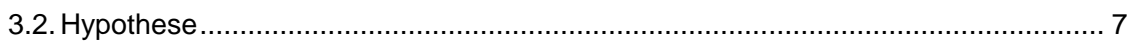

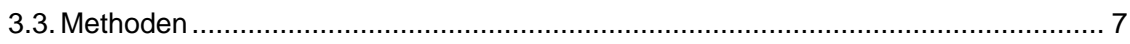

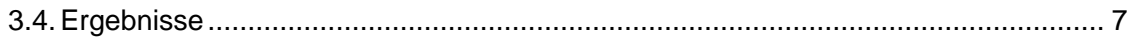

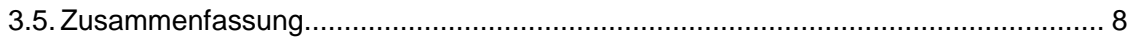

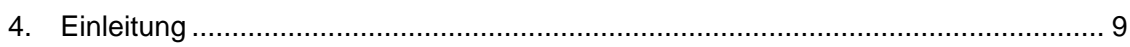

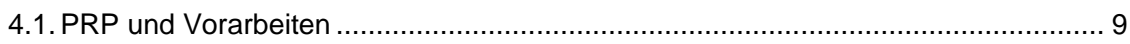

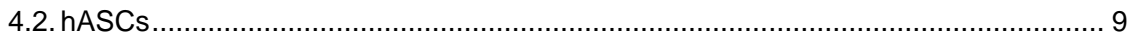

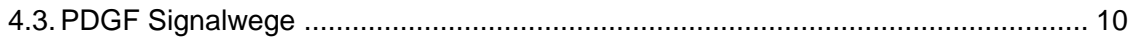

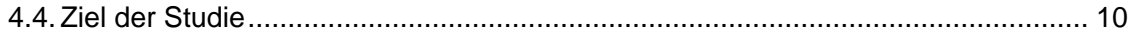

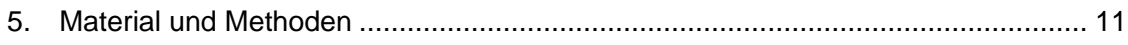

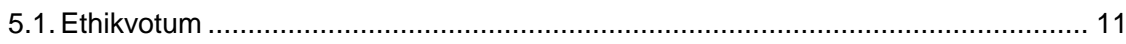

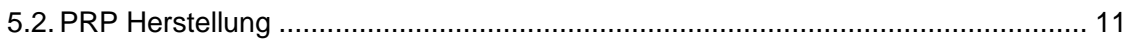

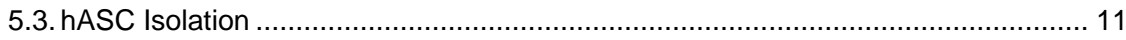

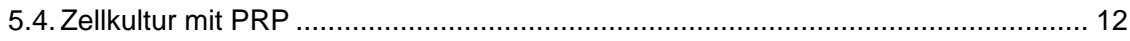

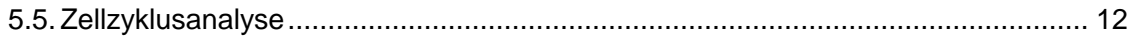

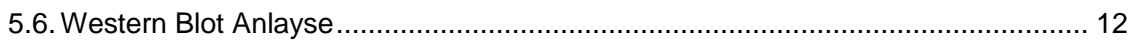

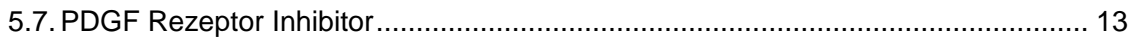

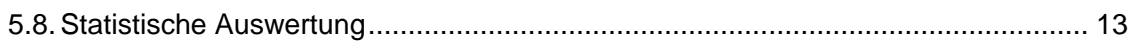

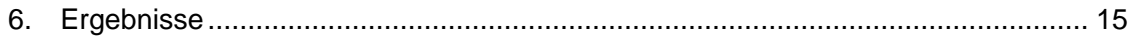


6.1. Zeitabhängige Effekte von PRP auf die hASC Proliferation ................................ 15

6.2. Der zeitabhängige Einfluss von PRP auf die Proteinexpression von hASCs .......... 15

6.3. PRP stimuliert die Proliferation von hASCs über den PDGF Rezeptor ß ............... 15

6.4. Einfluss der PDGF Rezeptor $\beta$ Blockade auf die Proteinexpression von PRPsupplementierten hASCs nach 48 Stunden Inkubation ................................... 16

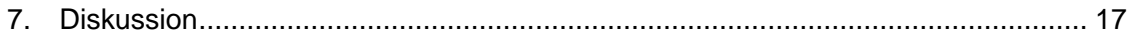

7.1. Zeitabhängiger Effekt von PRP auf die Proliferation von MSCs.......................... 17

7.2. Die Bedeutung der PDGF Signaltransduktion .................................................. 17

7.3. Die Bedeutung der c-MYC Signaltransduktion .............................................. 18

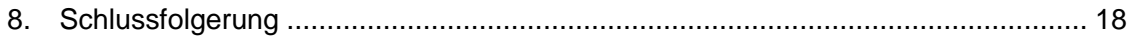

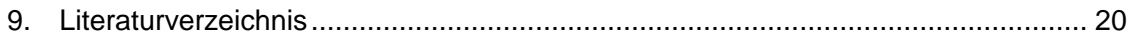

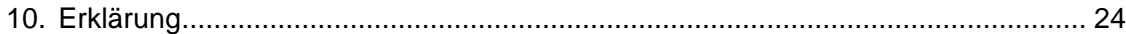

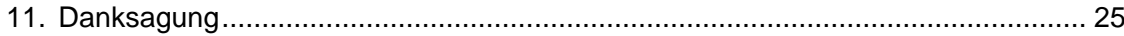

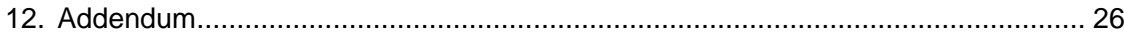

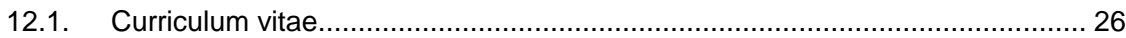

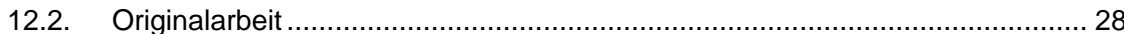


2. Abkürzungsverzeichnis

\begin{tabular}{|c|c|}
\hline a-MEM & a-Minimum eagel medium \\
\hline $\mathrm{cm}$ & Zentimeter \\
\hline DAPI & 4',6-Diamidin-2-phenylindol \\
\hline FCS & Fetal Calf Serum \\
\hline g & Gramm \\
\hline GAPDH & Glycerinaldehyd-3-phosphat-Dehydrogenase \\
\hline GMP & Good manufacturing practice \\
\hline hASC & Human adipose-tissue-derived mesenchymal stem cells \\
\hline MAPK & Mitogen-activated protein kinase \\
\hline MAP2K1 & Mitogen-activated protein kinase kinase \\
\hline MEK1 & $=\mathrm{MAP} 2 \mathrm{~K} 1$ \\
\hline$\mu g$ & Mikrogramm \\
\hline $\mathrm{mg}$ & Milligramm \\
\hline$\mu \mathrm{l}$ & Mikroliter \\
\hline $\mathrm{ml}$ & Milliliter \\
\hline$\mu \mathrm{M}$ & Mikromol \\
\hline M & Mol \\
\hline MSC & Mesenchymal stem cells \\
\hline $\mathrm{nm}$ & Nanometer \\
\hline PDGF & Platelet derived growth factor \\
\hline PDGF Rezeptor $\beta$ & Platelet derived growth factor receptor $\beta$ \\
\hline PLC Y & Phosphoinositide phospholipase $Y$ \\
\hline PI3K & Phosphatidylinositid 3-Kinase \\
\hline PRP & Platelet-rich Plasma \\
\hline SDS-PAGE & Sodium dodecyl sulfate polyacrylamide gel electrophoresis \\
\hline SPF & S-Phase Fraction \\
\hline $\mathrm{U}$ & Unit \\
\hline VEGF & Vascular endothelial growth factor \\
\hline
\end{tabular}




\section{Zusammenfassung}

\subsection{Hintergrund}

PRP wird in der aktuellen Literatur als ein xenoprotein-freier Zusatz für Zellkulturmedium in Modellen mit MSCs zur Stimulation der Proliferation vorgeschlagen. Über den Einfluss von PRP und den darin enthaltenen Wachstumsfaktoren auf die Entwicklung von MSCs existieren nur begrenzte Informationen.

\subsection{Hypothese}

Leukozyten-reduziertes PRP erhöht die Proliferation von hASCs abhängig von der Inkubationszeit und angewandten Dosierung über die PDGF Signaltransduktion und stellt eine Alternative zu bovinen Zusätzen in Standard-Labormedien dar.

\subsection{Methoden}

Leukozyten-reduziertes PRP wurde mittels eines kommerziell-erhältlichen PRP Kits gewonnen. HASCs wurden von 4 gesunden Patienten gewonnen und in a-MEM mit einem Zusatz von 20\% fetalem Rinderserum (FCS) bis zur Konfluenz expandiert. Anschließend wurden die hASCs in a-MEM mit $10 \%$ oder $20 \%$ PRP oder $20 \%$ FCS für 72 Stunden inkubiert. Die SPF der hASCs wurde nach 6, 12, 24, 48 und 72 Stunden mittels Durchflusszytometrie bestimmt. Der Einfluss von $10 \mathrm{ng} / \mu \mathrm{l}$ der rekombinanten PDGF Subtypen AA, AB und BB auf die Proliferation der ASCs wurde nach 48 Stunden gemessen. Außerdem wurden $3 \mu \mathrm{M}$ PDGF-Rezeptor $\beta$ Inhibitor zu den hASCs hinzugefügt, gefolgt von Inkubation mit a-MEM mit 20\% FCS oder $20 \%$ PRP für 48 Stunden. Erneut wurde die SPF der hASCs mit und ohne Rezeptorblockade bestimmt. Zusätzlich wurde die Expression des PDGF Rezeptor $\beta$ Proteins mittels Western Blot gemessen.

\subsection{Ergebnisse}

Die SPF der hhASCs unter Einfluss von 20\% PRP nimmt bis zu einer Inkubationszeit von 48 Stunden zu und ist signifikant höher im Vergleich zu der SPF der Zellen, die in Medium mit 20\% FCS oder 10\% PRP Zusatz inkubiert wurden $(P<0,01)$. Die SPF der ASCs unter Zusatz von 10\% PRP fällt nach 48 Stunden im Vergleich zu den 
vorangehenden Werten signifikant ab $(P<0,01)$. Unter Einfluss von 20\% PRP nimmt die SPF der hASCs nach 72 Stunden signifikant ab $(P<0,01)$. Zum 48 Stunden Zeitpunkt zeigt sich eine signifikant höhere SPF in hASCs, die mit den rekombinanten PDGF Subtypen $A B$ und -BB inkubiert wurden im Vergleich zu Zellen unter Einfluss des PDGF Subtyps AA oder von 20\% FCS Medienzusatz $(P<0,05)$. Die PDGF Rezeptorblockade führt dazu, dass nach 48 Stunden Inkubation mit 20\% PRP Medienzusatz keine Erhöhung der SPF im Vergleich zu den mit 20\% FCS Medienzusatz inkubierten Zellen zu finden ist $(P<0,01)$. Die PDGF Rezeptor $\beta$ Expression in hASCs unter Einfluss von $20 \%$ PRP ist signifikant reduziert im Vergleich zu der Expression in Zellen unter dem Einfluss von $20 \%$ FCS $(P<0,01)$. Hingegen ist die Expression von PDGF Rezeptor $\beta$ nach der Rezeptorblockade in den mit 20\% PRP Zusatz inkubierten hASCs signifikant höher im Vergleich zu den Zellen ohne Rezeptorblockade $(P<0,01)$.

\subsection{Zusammenfassung}

Die Proliferation und Proteinexpression von hASCs, die mit 20\% PRP Medienzusatz kultiviert werden, sind abhängig von der PDGF-Signaltransduktion, ausgehend vom PDGF Rezeptor $\beta$. Bei der Wahl der optimalen Wachstumsfaktorkonzentration für die Zellkultur sollte die Regulierung von PDGF Rezeptor $\beta$ in PRP-stimulierten hASCs beachtet werden. Unsere Ergebnisse legen nahe, dass PRP eine effiziente Ergänzung für Zellkulturmedium für die autologe hASC Expansion über 48 Stunden darstellt. 


\section{Einleitung}

\subsection{PRP und Vorarbeiten}

In den vergangenen Jahren wurden zahlreiche Therapiemethoden basierend auf der Applikation von PRP etabliert [1,2]. Der therapeutische Effekt wird vor allem auf die bioaktiven Proteine, insbesondere Wachstumsfaktoren wie PDGF und VEGF und Zytokine zurückgeführt [3,4]. Vielen Studienprotokollen mangelt es jedoch an einer quantitativen Bestimmung der PRP Bestandteile. Auf Grund zahlreicher verschiedener PRP Herstellungsmethoden sind die Ergebnisse der klinischen Untersuchungen oft kontrovers [5-7]. Die Zusammensetzung von PRP stellt eine heterogene Mischung aus bioaktiven Substanzen dar und weist eine hohe biologische Variabilität auf. Der für den Effekt von PRP auf Stammzellen verantwortliche Bestandteil wurde bislang nicht abschließend identifiziert. Deshalb führten wir zunächst eine Charakterisierung eines kommerziell erhältlichen PRP Produkts durch. Durch die Modifikation der Zentrifugationseinstellungen erreichten wir eine Reduktion der im Produkt enthaltenen Leukozyten und zeigten einen positiven Effekt des leukozyten-armen PRPs auf die Proliferation von hASCs [8]. Außerdem konnten wir in einer klinischen Pilotstudie einen positiven therapeutischen Effekt zweimaliger intraartikulärer PRP Injektionen bei Rhizarthrose nachweisen [9].

\section{2. hASCs}

Mesenchymale Stammzellen sind zentraler Bestandteil regenerativer Therapien, die ein Differentierungspotential in verschiedene Zellinien aufweisen, die Fähigkeit zur parakrinen Sekretion besitzen und mit geringem Aufwand aus verschiedenen Geweben, zum Beispiel Fettgewebe (hASCs) gewonnen werden können [10-12]. Um eine ausreichend hohe Zellzahl für die klinische Anwendung zu erreichen, müssen hASCs in vielen Anwendungsprotokollen zunächst in vitro expandiert und gegebenenfalls differenziert werden. In den meisten Zellkulturprotokollen wird dabei bovines Serum als Zusatz für das Nährmedium verwendet [13]. Eine zunehmende Anzahl an Studien beschreibt PRP als eine Xenoprotein-freie Alternative $\mathrm{zu}$ bovinem Serum als Nährmediumzusatz [14-17]. Bislang ist unzureichend erforscht, über welche 
Signalwege PRP die zellulären Mechanismen in hASCs beeinflusst und über welche Rezeptoren die bioaktiven Proteine in PRP auf hASCs wirken.

\subsection{PDGF Signalwege}

Neben anderen Wachstumsfaktoren spielt PDGF eine entscheidende Rolle in der Stimulation der Proliferation von MSCs [18,19]. Die verschiedenen PDGF homo- und heterodimere aktivieren die zellwandständigen PDGF Rezeptoren Typ $\alpha$ und $\beta$, woraufhin unter anderen der PI3K, PLC $y$ und der MAPK Signalweg aktiviert werden $[20,21]$. In einer vorangegangenen Studie konnten wir PDGF Rezeptor $\beta$ und c-MYC als stark regulierte Proteine in hASCs unter PRP Einfluss identifizieren [22]. Zurzeit existieren nicht ausreichend Informationen über die Art und Weise wie die Wachstumsfaktoren die Proliferation in MSCs anregen. Die Identifizierung der durch PRP in MSCs ausgelösten Signaltransduktionswege wird dazu beitragen PRP als verlässlichen Zellkulturmediumzusatz zu etablieren.

\subsection{Ziel der Studie}

Das Ziel der vorliegenden Studie war, die Rolle der PDGF Signaltransduktion bei der Proliferation von hASCs in der Zellkultur mit PRP Supplementation zu untersuchen mit der Hypothese, dass leukozyten-reduziertes PRP die Proliferation von hASCs abhängig von der Inkubationszeit und angewandten Dosierung über die PDGF Signaltransduktion erhöht. 


\section{Material und Methoden}

\subsection{Ethikvotum}

Die vorliegende Studie wurde durch die Ethikkommission der Universität Regensburg genehmigt und die schriftliche Einverständniserklärung wurde von jedem Teilnehmer der Studie gemäß der Deklaration von Helsinki eingeholt.

\subsection{PRP Herstellung}

Zur Herstellung von PRP wurden 15ml venöses Blut direkt in ein Doppelspritzensystem (Arthrex, Inc., Naples, Florida, USA) aufgezogen. Dazu wurden Butterfly Blutentnahmesets (Sarstedt AG \& Co., Nümbrecht, Germany) benutzt. Das venöse Vollblut wurde mittels einer Hettich Rotofix 32a Zentrifuge bei 1500 rpm für 4 Minuten ohne Bremsvorgang zentrifugiert. In einer vorangehenden Arbeit konnte an Proben von 30 gesunden Erwachsenen aus 3 Altersdekaden durch den Vergleich von 3 verschiedenen Zentrifugationsmethoden gezeigt werden, dass durch diese Einstellungen eine Thrombozytenkonzentration von 548,5 $\pm 104,9 \times 10^{3} / \mu \mathrm{lm}$ Plasma erreicht werden kann, bei einem Gehalt der weißen Blutzellen von 0,05 $\pm 0,11 \times 10^{3} / \mu \mathrm{l}$ [8]. Das Blut wurde in eine Plasmaschicht und eine Schicht mit den roten Blutzellen getrennt. Die obenliegende Plasmaschicht mit den darin enthaltenen Thrombozyten (PRP) wurde gemäß den Herstellervorgaben in der inneren Spritze des Doppelspritzensystems isoliert. Die PRP Proben wurden unmittelbar nach der Zentrifugation bei $-20^{\circ} \mathrm{C}$ gelagert. Für die weiteren Untersuchungen wurden die PRP Proben aufgetaut und somit aktiviert. Für alle Experimente wurden gepoolte PRP Proben von 4 Spendern verwendet.

\section{3. hASC Isolation}

HASCs wurden aus subkutanem Fettgewebe von 4 Patienten nach einem bereits etablierten Protokoll gewonnen [8]. Die Proben wurden innerhalb von 24 Stunden nach der Isolation verarbeitet. Das Gewebe wurde zerkleinert und mit Liberase Blendzyme 3 (Roche Diagnostics, Rotkreuz, Switzerland) (2 U/g Gewebe) für 45 Minuten inkubiert. Durch Filterung und Zentrifugation wurde ein Zellpellet gewonnen, welches in Standard 
Medium (20\% FCS) resuspendiert wurde. 3,0 x 104 Zellen $/ \mathrm{cm}^{2}$ wurden in einer $175 \mathrm{~cm}^{2}$ Flasche unter Standardbedingungen bis zu einer Konfluenz von $80 \%$ kultiviert und in Passage 0 für die weiteren Experimente eingefroren.

\subsection{Zellkultur mit PRP}

$2,5 \times 10^{5}$ hASC in Passage 1 bis 2 wurden in $100 \mathrm{~mm}$ Zellkulturschalen gegeben und für 48 Stunden unter Standardbedingungen kultiviert. Anschließend wurde das Kulturmedium für 24 Stunden gegen serumfreies Medium ausgetauscht, um eine Synchronisation der Zellen im Zellzyklus zu erreichen. Schließlich wurde das Medium gegen die Testmedien der 6 Gruppen ausgetauscht: Gruppe 1: a-MEM mit 20\% FCS (Standard), Gruppe 2: a-MEM mit 20\% FCS mit 10ng/ml rekombinatem PDGF-AA, Gruppe 3: $\alpha$-MEM mit 20\% FCS mit $10 \mathrm{ng} / \mathrm{ml}$ rekombinatem PDGF-AB, Gruppe 4: $\alpha$ MEM mit 20\% FCS mit 10ng/ml rekombinatem PDGF-BB Gruppe 5: a-MEM mit 10\% PRP, Gruppe 6: a-MEM mit 20\% PRP. Unmittelbar nach der Synchronisation wurden die Kontrollproben entnommen (T0). Die Zellen wurden jeweils für 6, 12, 24, 48 und 72 Stunden inkubiert und für die Zellzyklusanalyse und die Western Blot Untersuchung durch Trypsination geerntet.

\subsection{Zellzyklusanalyse}

Die geernteten Zellen wurden nach einem etablierten Protokoll gereinigt und mit $1 \mu \mathrm{g} / \mathrm{ml}$ DAPI versetzt [8]. Anschließend wurden $3 \times 10^{5}$ DAPI gefärbte Zellen der Durchflusszytometrie zugeführt. Dazu wurde ein FACSCanto-II Durchflusszytometer (BD Biosciences, San Jose, CA, USA) verwendet. Anhand der DNA Histogrammen konnten durch die ModFit LT 3.2 Software (Verity Software House, Topsham, ME, USA) die Zellzyklusfraktionen, also der prozentuale Anteil der Zellen in der G0/G1-, S- and G2/MPhase bestimmt werden. Ein proliferationsfördernder Effekt wurde dabei durch einen erhöhten Anteil von Zellen in der S-Phase (S-Phase Fraktion) ausgedrückt.

\subsection{Western Blot Anlayse}

Die Zellen wurden gemäß den Herstellervorgaben für die Western Blot Analyse vorbereitet und lysiert, die Proteine wurden auf dem SDS-PAGE Gel aufgetrennt und auf 
eine Polyvinylden Diflurid Membran übertragen. Die Membran wurde geblockt und mit anti PDGF Rezeptor $\beta$ Antikörper (rabbit, ab32570, 1:1000), anti-c-MYC (rabbit, ab32072, 1:5000), und anti-GAPDH (mouse, ab8245, 1:5000) (alle Abcam, Cambridge, UK) für jeweils 1 Stunde inkubiert. Anschließend erfolgte die Inkubation mit den sekundären Antikörpern: anti-Maus IRDye 680 (goat, LI-COR 926-68070, 1:15000) und anti-Hase IRDye 800 (goat, LI-COR 926-32211, 1:15000). Die so markierten Proteine wurden mittels dem LI-COR Odyssey System und der LI-COR Image Studio Software (LI-COR Biosciences, Lincoln, Nevada, USA) gemessen.

\subsection{PDGF Rezeptor Inhibitor}

Der PDGF Signalweg wurde durch den selektiven PDGF Rezeptor $\beta$ Inhibitor CP673451 (Selleck Chemicals, Houston, Texas, USA) blockiert: $2,5 \times 10^{5}$ hASC in Passage 1 bis $2(n=3)$ wurden in einem $100 \mathrm{~mm}$ Petri dish für 48 Stunden unter Standardbedingungen und für weitere 24 Stunden in serumfreiem Medium kultiviert. Anschließend wurden die Zellen in a-MEM haltigem Medium mit einem Zusatz von $3 \mu \mathrm{M}$ Inhibitor für 30 Minuten inkubiert, bevor das Medium erneut gegen die Testmedien (20\% FCS oder 20\% PRP) ausgetauscht wurde und die Zellen weitere 48 Stunden inkubiert wurden. Im Anschluss erfolgte die Zellernte, Zellzyklus- und Western Blot Analyse wie beschrieben.

\subsection{Statistische Auswertung}

Die Statistische Auswertung erfolgte mit der SPSS Software (Version 19, IBM SPSS, Chicago, Illinois, USA). Alle Grafen wurden mit der GraphPad Prism Software (Version 5, Statcon, La Jolla, California, USA) erstellt. Die Daten wurden zunächst mittels des Shapiro Wilk Tests auf Normalverteilung getestet. Die deskriptiven Daten wurden als Mittelwerte \pm Standardabweichung (SD) dargestellt. Die statistischen Unterschiede in der SPF and Protein Expression der hASCs zu verschiedenen Messpunkten und mit verschiedenen Medienzusätzen, welche die Zellzyklus- und Western Blot Analysen ergaben, wurden mit der univariaten Varianzanlyse (ANOVA) mit Bonferroni Korrektur untersucht. Der gepaarte T-test mit Bonferroni Korrektur wurde angewandt, um statistische Unterschiede in der SPF and Protein Expression der hASCs mit und ohne 
PDGF Rezeptor $\beta$ Inhibitor zu identifizieren. Das Niveau der statistischen Signifikanz wurde mit $\mathrm{P}<0,05$ für alle statistischen Tests festgelegt. 


\section{Ergebnisse}

6.1. Zeitabhängige Effekte von PRP auf die hASC Proliferation Die durchflusszytometrische Untersuchung der hASCs zeigte eine erhöhte SPF der $h$ ASCs unter Einfluss von 20\% FCS von 4,6 $\pm 1,6 \%$ (T0), 4,4 $\pm 2,8 \%$ nach 6 Stunden und $3,6 \pm 1,3 \%$ nach 12 Stunden, mit dem höchsten Wert nach 24 Stunden $(21,8 \pm 12,0 \%)$. Nach 48 Stunden fiel die SPF auf 10,2 $\pm 4,1 \%$ und auf 8,1\% $\pm 3,2 \%$ nach 72 Stunden. Ein ähnlicher Verlauf wurde in der Anwesenheit von 10\% PRP beobachtet: Von 3,2 \pm $0,7 \%$ auf $4,0 \pm 1,9 \%$, auf $33,9 \pm 12,4 \%$, auf $7,0 \pm 2,7 \%$, auf $5,8 \pm 1,3 \%$. Unter Einfluss von $20 \%$ PRP zeigte sich der SPF Anstieg nach 24 Stunden mit 25,6 $\pm 10,8 \%$ noch deutlicher. Die höchste SPF von $32,1 \pm 3,8 \%$ wurde nach 48 Stunden nachgewiesen und fiel nach 72 Stunden signifikant auf $5,8 \pm 0,7 \%$ ab $(P<0,01)$. Im Vergleich zu $10 \%$ PRP und 20\% FCS war die SPF der ASCs unter Einfluss von 20\% PRP nach 48 Stunden Inkubation signifikant erhöht (beide $P<0,01$ ).

\subsection{Der zeitabhängige Einfluss von PRP auf die Proteinexpression von hASCs}

Die Western Blot Analyse der PDGF Rezeptor $\beta$ Expression von hASCs im Standardlabormedium ergab eine maximale Konzentration nach 12 Stunden Inkubation. Die PDGF Rezeptor $\beta$ Konzentration in Zellen, die mit $10 \%$ oder $20 \%$ PRP inkubiert wurden, zeigte einen Peak nach 6 Stunden Inkubation und fiel daraufhin auf ein konstant niedriges Level ab.

Die c-MYC-Expression in ASCs, die im Standardlabormedium kultiviert wurden, zeigte einen signifikanten Peak nach 12 Stunden im Vergleich zum Ausgangswert T0 ( $P$ $<0,05)$. Hingegen führte $10 \%$ und $20 \%$ PRP Medien Supplementierung zu einem signifikanten Höhepunkt der c-MYC-Expression nach 48 Stunden im Vergleich zu allen vorherigen Zeitpunkten (alle $\mathrm{P}<0,05$ ).

\subsection{PRP stimulierte die Proliferation von hASCs über den PDGF Rezeptor $B$}

Die Zugabe des PDGF Rezeptor $\beta$ Inhibitors führte zu einer signifikanten Reduktion der SPF der in 20\% PRP inkubierten Zellen ( $<0,01)$. Im Gegensatz dazu hatte die PDGF 
Rezeptor $\beta$ Blockade keinen signifikanten Einfluss auf die Proliferation der Zellen, welche im Standardlabormedium kultiviert wurden.

Durch die Supplementation mit 10ng der rekombinanten PDGF Subtypen AB und BB ließ sich nach 48 Stunden ebenfalls eine signifikante Erhöhung der SPF auf 17,0 $\pm 3,5 \%$ bzw. auf 22,0 $\pm 5,1 \%$ im Vergleich zur Supplementation mit 20\% FCS allein oder mit PDGF Subtyp AA erreichen (alle $\mathrm{P}<0,05$ ).

6.4. Einfluss der PDGF Rezeptor $\beta$ Blockade auf die Proteinexpression von PRPsupplementierten hASCs nach 48 Stunden Inkubation

Die PDGF-Rezeptor- $\beta$-Expression war signifikant niedriger in ASCs, die 48 Stunden in Gegenwart von $20 \%$ PRP $(0,10 \pm 0,02)$ kultiviert wurden, im Vergleich zu $20 \%$ FCS $(0,46 \pm 0,01)(P<0,01)$. Die Hemmung des PDGF-Rezeptors $\beta$ induzierte eine signifikante Abnahme der Expression des PDGF-Rezeptors $\beta$ in Gegenwart von $20 \%$ FCS (auf $0,09 \pm 0,02, P<0,01$ ). Im Gegensatz dazu induzierte die Hemmung des PDGF-Rezeptors $\beta$, eine signifikante Erhöhung der Expression des PDGF-Rezeptors $\beta$ in Gegenwart von 20\% PRP $(0,28 \pm 0,02, P<0,05)$.

Die C-MYC-Expression war signifikant höher in ASCs, welche 48 Stunden lang in Gegenwart von $20 \%$ PRP $(0,16 \pm 0,04)$ kultiviert wurden, im Vergleich zu 20\% FCS $(0,03 \pm 0,01, P<0,05)$. Die Hemmung des PDGF-Rezeptors $\beta$ induzierte eine signifikante Reduktion der C-MYC-Expression von ASCs in Gegenwart von 20\% FCS $(0,0003 \pm 0,0006)$ und $20 \% \operatorname{PRP}(0,002 \pm 0,001)$ (beide $P<0,05)$. 


\section{Diskussion}

7.1. Zeitabhängiger Effekt von PRP auf die Proliferation von MSCs Wie auch in vorangegangenen Arbeiten konnten wir in dieser Studie erneut den positiven Effekt von PRP auf die Proliferation von hASCs nachweisen [8,22]. Unter 20\% PRP Supplementation wird die Proliferation im Vergleich zum Standardlabormedium nach 24 und 48 Stunden signifikant erhöht. Dieser Effekt wurde auch von anderen Forschungsgruppen publiziert $[8,14,23]$.

In einer früheren Studie haben wir zudem die Zusammensetzung von dem in dieser Studie verwendeten PRP-Produkts analysiert und das Wachstumsfaktorprofil detailliert beschrieben [8]. Hier wurde die Heterogenität der PRP Zusammensetzung deutlich.

Van Pham et al. zeigten eine erhöhte Proliferationskurve von ASCs unter PRP Supplementation im Vergleich zu FCS über 105 Stunden [24]. In der vorliegenden Studie nimmt die SPF unter PRP Supplementation bis zu einer Inkubationszeit von 48 Stunden zu. Darüber hinaus ist im Gegensatz zu Van Pham et al. kein signifikanter proliferationsfördernder Effekt zu beobachten. Dies legt die Notwendigkeit eines Mediumwechsels in 72 Stunden-Abständen nahe.

\subsection{Die Bedeutung der PDGF Signaltransduktion}

Wie auch die vorliegenden Ergebnisse nahelegen, wurde bereits beschrieben, dass PRP die Proliferation von ASCs hauptsächlich über den PDGFR/AKT Signalweg anregt [17]. Wir zeigten außerdem, dass sich durch die rekombinanten PDGF Subtypen $A B$ und BB, welche mit dem PDGF Rezeptor $\beta$ interagieren [21] eine signifikante Erhöhung der Proliferationsrate von hASCs im Vergleich zu Standardlaborbedingungen erreichen lässt. Die zentrale Rolle des PDGF Rezeptors $\beta$ für den proliferationsfördernden Effekt von PRP wird in unserem Rezeptor Inhibitions-Versuch deutlich. Damit haben wir außerdem PDGF als entscheidenden Bestandteil im Wachstumsfaktorprofil von PRP zur Anregung der Proliferation von hASCs identifizieren können.

Interessanterweise ist ein negativer Feedbackmechanismus zwischen der PI3K/AKT und der PDGF Rezeptor $\beta$ Expression bekannt [25]. Auch unsere Ergebnisse weisen auf 
diesen Mechanismus hin. Wir konnten eine inverse Beziehung zwischen der PDGF Rezeptor $\beta$ Expression und der Zellproliferation der hASCs zeigen. Außerdem zeigten wir zum ersten Mal die Kinetik der PDGF Rezeptor Expression in hASCs unter Einfluss von PRP. Die progrediente Abnahme der Expression von PDGF Rezeptor $\beta$ kann durch den Effekt der Internalisation des Rezeptor Komplex in Endosomen, welche durch Ligandenbindung initiiert wird, erklärt werden [26]. Dies ist ein möglicher Grund dafür, weshalb höhere Konzentrationen von PRP einen inhibitorischen Effekt auf die Proliferation verschiedener Zelltypen haben [27,28].

\subsection{Die Bedeutung der C-MYC Signaltransduktion}

Der nukleäre Transkriptionsfaktor c-MYC ist als Schlüsselmediator der PDGFinduzierten Mitogenese bekannt [29]. Unsere Studie zeigt eine Zunahme der c-MYCExpression in mit PRP stimulierten Zellen. In einer Studie von Jones et al. wird nahe gelegt, dass es durch C-MYC, PI3K und MEK1 induzierte eine gemeinsame Signalkaskade gibt, mit der Mitogene den Progress von Zellen im Zellzyklus initiieren [30].

Es gilt zu beachten, dass die Überexpression des Onkoproteins c-MYC auch mit der Tumorentstehung korreliert und zu einer spontanen Transformation in MSCs führen könnte [30,31]. Bei der Beurteilung dieses Hauptrisikos für die klinische Anwendung zeigte eine erste Studie eine gute Resistenz der ASC gegenüber spontaner Transformation während der in vitro-Expansion in Gegenwart von gepooltem allogenem Humanserum, trotz hoher c-MYC-Proteinexpression [32].

\section{Schlussfolgerung}

Um den GMP Richtlinien für einen möglichen autologen Zellkulturansatz mit hASCs und PRP gerecht zu werden, ist ein tiefgreifendes Wissen über die zellulären Mechanismen nötig, welche von PRP induziert werden. Um eine optimale Proliferationsrate zu erzielen, ist eine Feinabstimmung der Wachstumsfaktorkonzentrationen notwendig. In der vorliegenden Studie konnten wir zeigen, dass PRP als Zellkulturzusatz eine verlässliche autologe hASC Kultivierung ermöglicht. Die Proliferation ist dabei von der 
PDGF Rezeptor $\beta$ Signaltransduktion abhängig. Wir konnten zeigen, dass PRP die Proliferation von hASCs im Vergleich zu Standardlabormedium über einen Zeitraum von 48 Stunden entscheidend erhöht. Zum ersten Mal wurde gezeigt, dass unter den vielzähligen, in PRP enthaltenen bioaktiven Proteinen PDGF bei der Proliferationsanregung von hASCs die tragende Rolle spielt.

20\% PRP ist ein hocheffektiver autologer Mediumzusatz, welcher in unserem Versuchsaufbau einen Medienwechsel alle 72 Stunden notwendig macht. Die exakte Rolle der Schlüsselproteine PDGF Rezeptor $\beta$ und c-MYC für die Differenzierung von hASCs muss in zukünftigen Studien genauer beleuchtet werden. 


\section{Literaturverzeichnis}

[1] Sundman EA, Cole BJ, Karas V, Della Valle C, Tetreault MW, Mohammed HO, et al. The anti-inflammatory and matrix restorative mechanisms of platelet-rich plasma in osteoarthritis. Am J Sports Med 2014;42:35-41. doi:10.1177/0363546513507766.

[2] Willits K, Kaniki N, Bryant D. The use of platelet-rich plasma in orthopedic injuries. Sports Med Arthrosc 2013;21:225-30. doi:10.1097/JSA.0000000000000001.

[3] Anitua E, Andia I, Ardanza B, Nurden P, Nurden AT. Autologous platelets as a source of proteins for healing and tissue regeneration. Thromb Haemost 2004;91:4-15. doi:10.1267/THRO04010004.

[4] Ferrari M, Zia S, Valbonesi M, Henriquet F, Venere G, Spagnolo S, et al. A new technique for hemodilution, preparation of autologous platelet-rich plasma and intraoperative blood salvage in cardiac surgery. Int J Artif Organs 1987;10:47-50.

[5] Lopez-Vidriero E, Goulding KA, Simon DA, Sanchez M, Johnson DH. The Use of Platelet-Rich Plasma in Arthroscopy and Sports Medicine: Optimizing the Healing Environment. Arthroscopy: The Journal of Arthroscopic \& Related Surgery 2010;26:26978. doi:10.1016/j.arthro.2009.11.015.

[6] Russell RP, Apostolakos J, Hirose T, Cote MP, Mazzocca AD. Variability of platelet-rich plasma preparations. Sports Med Arthrosc 2013;21:186-90. doi:10.1097/JSA.0000000000000007.

[7] Sánchez M, Anitua E, Andia I. Poor standardization in platelet-rich therapies hampers advancement. Arthroscopy 2010;26:725-726; author reply 726 . doi:10.1016/j.arthro.2010.03.002.

[8] Loibl M, Lang S, Brockhoff G, Gueorguiev B, Hilber F, Worlicek M, et al. The effect of leukocyte-reduced platelet-rich plasma on the proliferation of autologous adipose-tissue derived mesenchymal stem cells. Clin Hemorheol Microcirc 2014. doi:10.3233/CH-141920.

[9] Loibl M, Lang S, Dendl L-M, Nerlich M, Angele P, Gehmert S, et al. LeukocyteReduced Platelet-Rich Plasma Treatment of Basal Thumb Arthritis: A Pilot Study. Biomed Res Int 2016;2016:9262909. doi:10.1155/2016/9262909.

[10] Zuk PA, Zhu M, Mizuno H, Huang J, Futrell JW, Katz AJ, et al. Multilineage cells from human adipose tissue: implications for cell-based therapies. Tissue Eng 2001;7:211-28. doi:10.1089/107632701300062859.

[11] Hsiao ST-F, Asgari A, Lokmic Z, Sinclair R, Dusting GJ, Lim SY, et al. Comparative Analysis of Paracrine Factor Expression in Human Adult Mesenchymal 
Stem Cells Derived from Bone Marrow, Adipose, and Dermal Tissue. Stem Cells Dev 2012;21:2189-203. doi:10.1089/scd.2011.0674.

[12] Sadat S, Gehmert S, Song Y-H, Yen Y, Bai X, Gaiser S, et al. The cardioprotective effect of mesenchymal stem cells is mediated by IGF-I and VEGF. Biochemical and Biophysical Research Communications 2007;363:674-9. doi:10.1016/j.bbrc.2007.09.058.

[13] Coleman SR. Structural fat grafting: more than a permanent filler. Plast Reconstr Surg 2006;118:108S-120S. doi:10.1097/01.prs.0000234610.81672.e7.

[14] Bieback K, Hecker A, Kocaömer A, Lannert H, Schallmoser K, Strunk D, et al. Human alternatives to fetal bovine serum for the expansion of mesenchymal stromal cells from bone marrow. Stem Cells 2009;27:2331-41. doi:10.1002/stem.139.

[15] Kocaoemer A, Kern S, Klüter H, Bieback K. Human AB Serum and ThrombinActivated Platelet-Rich Plasma Are Suitable Alternatives to Fetal Calf Serum for the Expansion of Mesenchymal Stem Cells from Adipose Tissue. Stem Cells 2007;25:12708. doi:10.1634/stemcells.2006-0627.

[16] Atashi F, Jaconi MEE, Pittet-Cuénod B, Modarressi A. Autologous Platelet-Rich Plasma: A Biological Supplement to Enhance Adipose-Derived Mesenchymal Stem Cell Expansion. Tissue Engineering Part C: Methods 2014;21:253-62. doi:10.1089/ten.tec.2014.0206.

[17] Tchang LA, Pippenger BE, Todorov A, Wolf F, Burger MG, Jaquiery C, et al. Pooled thrombin-activated platelet-rich plasma: a substitute for fetal bovine serum in the engineering of osteogenic/vasculogenic grafts: PRP as a substitute for FBS in engineering vascularized bone grafts. Journal of Tissue Engineering and Regenerative Medicine 2015. doi:10.1002/term.2054.

[18] Mazzocca AD, McCarthy MBR, Chowaniec DM, Dugdale EM, Hansen D, Cote MP, et al. The Positive Effects of Different Platelet-Rich Plasma Methods on Human Muscle, Bone, and Tendon Cells. The American Journal of Sports Medicine 2012;40:1742-9. doi:10.1177/0363546512452713.

[19] Ng F, Boucher S, Koh S, Sastry KSR, Chase L, Lakshmipathy U, et al. PDGF, TGF-, and FGF signaling is important for differentiation and growth of mesenchymal stem cells (MSCs): transcriptional profiling can identify markers and signaling pathways important in differentiation of MSCs into adipogenic, chondrogenic, and osteogenic lineages. Blood 2008;112:295-307. doi:10.1182/blood-2007-07-103697.

[20] Fredriksson L, Li H, Eriksson U. The PDGF family: four gene products form five dimeric isoforms. Cytokine \& Growth Factor Reviews 2004;15:197-204. doi:10.1016/j.cytogfr.2004.03.007. 
[21] Andrae J, Gallini R, Betsholtz C. Role of platelet-derived growth factors in physiology and medicine. Genes Dev 2008;22:1276-312. doi:10.1101/gad.1653708.

[22] Loibl M, Lang S, Hanke A, Herrmann M, Huber M, Brockhoff G, et al. Leukocytereduced platelet-rich plasma alters protein expression of adipose-tissue derived mesenchymal stem cells. Accepted Plastic and Reconstructive Surgery Jan 2016 n.d.

[23] Cho HS, Song IH, Park S-Y, Sung MC, Ahn M-W, Song KE. Individual variation in growth factor concentrations in platelet-rich plasma and its influence on human mesenchymal stem cells. Korean J Lab Med 2011;31:212-8. doi:10.3343/kjlm.2011.31.3.212.

[24] Van Pham P, Vu NB, Phan NL-C, Le DM, Truong NC, Truong NH, et al. Good manufacturing practice-compliant isolation and culture of human adipose derived stem cells. Biomedical Research and Therapy 2014;1. doi:10.7603/s40730-014-0021-6.

[25] Gharibi B, Ghuman MS, Hughes FJ. Akt- and Erk-mediated regulation of proliferation and differentiation during PDGFR $\beta$-induced MSC self-renewal. J Cell Mol Med 2012;16:2789-801. doi:10.1111/j.1582-4934.2012.01602.x.

[26] Sorkin A, Westermark B, Heldin C-H, Claesson-Welsh L. Effect of receptor kinase inactivation on the rate of internalization and degradation of PDGF and the PDGF betareceptor. The Journal of Cell Biology 1991;112:469-478.

[27] Tchang LA, Pippenger BE, Todorov A, Wolf F, Burger MG, Jaquiery C, et al. Pooled thrombin-activated platelet-rich plasma: a substitute for fetal bovine serum in the engineering of osteogenic/vasculogenic grafts: PRP as a substitute for FBS in engineering vascularized bone grafts. Journal of Tissue Engineering and Regenerative Medicine 2015. doi:10.1002/term.2054.

[28] Weibrich G, Hansen T, Kleis W, Buch R, Hitzler WE. Effect of platelet concentration in platelet-rich plasma on peri-implant bone regeneration. Bone 2004;34:665-71. doi:10.1016/j.bone.2003.12.010.

[29] Bowman T, Broome MA, Sinibaldi D, Wharton W, Pledger WJ, Sedivy JM, et al. Stat3-mediated Myc expression is required for Src transformation and PDGF-induced mitogenesis. Proc Natl Acad Sci U S A 2001;98:7319-24. doi:10.1073/pnas.131568898.

[30] Jones SM, Kazlauskas A. Growth-factor-dependent mitogenesis requires two distinct phases of signalling. Nat Cell Biol 2001;3:165-72. doi:10.1038/35055073.

[31] O'Donnell KA, Yu D, Zeller KI, Kim J-W, Racke F, Thomas-Tikhonenko A, et al. Activation of transferrin receptor 1 by $\mathrm{c}-\mathrm{Myc}$ enhances cellular proliferation and tumorigenesis. Mol Cell Biol 2006;26:2373-86. doi:10.1128/MCB.26.6.2373-2386.2006.

[32] Paula AC, Martins TM, Zonari A, Frade SP, Angelo PC, Gomes DA, et al. Human adipose tissue-derived stem cells cultured in xeno-free culture condition enhance c-MYC 
expression increasing proliferation but bypassing spontaneous cell transformation. Stem Cell Research \& Therapy 2015;6. doi:10.1186/s13287-015-0030-4. 
10. Erklärung

\section{ERKLÄRUNG ZUM PROMOTIONSVERFAHREN}

nach $\S 3$ Abs. 3 und 4 der Promotionsordnung

der Fakultät für Medizin der Universität Regensburg

Name: Lang

Vorname: Siegmund Philipp

geb. am: 09.10.1990

in: Landau a.d. Isar

Ich erkläre,

- $\quad$ dass ich den Doktorgrad der Medizin nicht schon an einer Hochschule der Bundesrepublik Deutschland erworben habe.

- $\quad$ dass ich nicht an anderer Stelle zu einem Promotionsverfahren zum Erwerb des medizinischen Doktorgrades zugelassen bin.

- $\quad$ dass ich die medizinische Doktorprüfung nicht schon an einer Hochschule der Bundesrepublik Deutschland endgültig nicht bestanden habe.

Außerdem erkläre ich,

- dass mir keine Tatsachen bekannt sind, die mich zur Führung eines akademischen Grades im Sinne des Gesetzes über die Führung akademischer Grade unwürdig erscheinen lassen.

- dass ich die vorliegende Arbeit ohne unzulässige Hilfe Dritter und ohne Benutzung anderer als der angegebenen Hilfsmittel angefertigt habe. Die aus anderen Quellen direkt oder indirekt übernommenen Daten und Konzepte sind unter Angabe der Quelle gekennzeichnet. Insbesondere habe ich nicht die entgeltliche Hilfe von Vermittlungs- bzw. Beratungsdiensten (Promotionsberater oder andere Personen) in Anspruch genommen. Niemand hat von mir unmittelbar oder mittelbar geldwerte Leistungen für Arbeit erhalten, die im Zusammenhang mit dem Inhalt der vorgelegten Dissertation stehen. Die Arbeit wurde bisher weder im In- noch im Ausland in gleicher oder ähnlicher Form einer anderen Prüfungsbehörde vorgelegt. 


\section{Danksagung}

An dieser Stelle möchte ich meinen uneingeschränkten Dank nachstehenden Personen entgegenbringen, ohne deren Mithilfe die Anfertigung dieser Dissertation niemals zustande gekommen wäre.

Mein besonderer Dank gilt meinem Doktorvater, Herrn PD Dr. Markus Loibl für die Überlassung des spannenden und aktuellen Themas. Außerdem für die exzellente Betreuung während allen Phasen meiner Dissertation und für seine Freundschaft. Trotz intensivster Arbeitsbelastung und wissenschaftlichen Verpflichtungen nahm er sich immer Zeit und stand mir mit fachkundigem Rat zur Seite.

Herrn Prof. Dr. Michael Nerlich möchte ich für die Bereitstellung des Arbeitsplatzes danken, sowie für fachkundige Anregungen während diversen Forschungsmeetings, durch welche meine Arbeit maßgeblich vorangebracht werden konnte.

Herr PD Dr. Sebastian Gehmert hat mich initial für den Themenkomplex der Stammzellforschung begeistert, er hat die methodischen Voraussetzungen zur Durchführung dieser Arbeit etabliert und mich hervorragend in Zusammenarbeit mit Herrn PD Dr. Loibl bei der Anfertigung und Veröffentlichung meiner Dissertation betreut. Hierfür gilt inm mein besonderer Dank.

Außerdem danke ich Herrn Prof. Dr. Dr. Lukas Prantl für die Möglichkeit, meine Arbeit auf einschlägigen Kongressen präsentieren zu dürfen.

Für die Unterstützung am Flow Cytometer möchte ich mich herzlich bei Prof. Dr. Gero Brockhoff und Herrn Gerhard Piendl bedanken, die mir einen reibungslosen Ablauf der Messungen ermöglichten.

Bei Frau Elke Gerstl und meinem Mitdoktoranden Alexander Hanke möchte ich mich für die lehrreiche Zeit im Labor und die hochmotivierte Arbeitsatmosphäre bedanken.

Für ihre wissenschaftliche Unterstützung bei der Studienplanung und für ihr regelmäßiges Feedback bei der Durchführung und Auswertung der Studie möchte ich mich herzlich bei Frau Dr. Marietta Herrmann bedanken.

Bei meinen Eltern Jasmin und Siegmund Lang sen. möchte ich mich dafür bedanken, dass sie mir mein Studium ermöglichten und mir auch während der Anfertigung der Dissertation immer mit Rat und Tat zu Seite standen.

Nicht genug danken kann ich meiner Ehefrau Judith Lang für ihre uneingeschränkte Unterstützung, ihre kundigen Ratschläge und ihre Ermunterungen bei der Anfertigung der Dissertation und bei der Veröffentlichung der zugehörigen Publikation. 


\section{Addendum}

12.1. Curriculum vitae

Name: $\quad$ Siegmund Philipp Lang

Geburtsdatum: $\quad$ 09. Oktober 1990

Geburtsort: $\quad$ Landau a. d. Isar

Nationalität: deutsch

Familienstatus: $\quad$ verheiratet mit Frau Judith Christina Lang

Schule:

1997-2001 Grundschule Kronwieden

2001-2010 Gymnasium Dingolfing, Abitur

06/2006 Oak Hills High School, Cincinnati, Ohio (USA)

\section{Studium}

2010 - $2016 \quad$ Medizin, Universität Regensburg (Abschluss der Ärztlichen Prüfung)

11/2015 - 03/2016 Spital Davos (Chirurgie), Schweiz

03/2016 - 06/2016 Krankenhaus Barmherzige Brüder Regensburg (Innere Medizin), Deutschland

06/2016 - 10/2016 Schulthess Klinik Zürich (Orthopädie), Schweiz

\section{Facharztausbildung}

Seit 01/2017 Assistenzarzt an der Klinik und Poliklinik für Unfallchirurgie, Klinikum der Universität Regensburg

\section{Forschungstätigkeit}

Seit 2013 Labor für Experimentelle Unfallchirurgie, Klinikum der Universität Regensburg

\section{Kongressteilnahmen}

06/2017 Deutsche Gesellschaft für Mikrozirkulation und Hämorheologie e. V. 36. Jahrestagung, Greifswald, Deutschland

10/2016 Deutscher Kongress für Orthopädie und Unfallchirurgie, Berlin, Deutschland

09/2016

33. AGA Kongress, Basel, Schweiz

11/2015 Deutsche Gesellschaft für Mikrozirkulation und Hämorheologie e. V. 34. Jahrestagung, Regensburg, Deutschland 
Deutscher Kongress für Orthopädie und Unfallchirurgie Berlin, Deutschland

\section{Publikationen}

- Lang S, Herrmann M, Pfeifer C, Brockhoff G, Zellner J, Nerlich M, Angele P, Prantl L, Gehmert S, Loibl M

Leukocyte-reduced platelet-rich plasma stimulates the in vitro proliferation of adipose-tissue derived mesenchymal stem cells depending on PDGF signaling. Clin Hemorheol Microcirc. 2017 Sep 11

- $\quad$ Hilber F; Loibl M, Lang S; Brockhoff G, Angele P, Zellner J, Schmitz P, Nerlich M, Worlicek M.

The effect of leukocyte-reduced platelet-rich plasma on the proliferation of tenocytes treated with prednisolone: a cellcycle analysis.

Arch Orthop Trauma Surg. 2017 Oct

- Loibl M, Lang S, Hanke A, Herrmann M, Huber M, Brockhoff G, Klein S, Nerlich M, Angele P, Prantl L, Gehmert S.

Leukocyte-reduced platelet-rich plasma alters protein expression of adiposetissue derived mesenchymal stem cells.

Plast Reconstr Surg. 2016 Apr 6.

- Loibl M, Lang S, Brockhoff G, Gueorguiev B, Hilber F, Worlicek M, Baumann F, Grechenig S, Zellner J, Huber M, Valderrabano V, Angele P, Nerlich M, Prantl L, Gehmert S.

The effect of leukocyte-reduced platelet-rich plasma on the proliferation of autologous adipose-tissue derived mesenchymal stem cells.

Clin Hemorheol Microcirc. 2016.

- $\quad$ Lang S, Brockhoff G, Gueorguiev, Huber M, Zellner J, Angele P, Prantl L, Nerlich M, Gehmert S, Loibl M.

Modifikation der Zentrifugation zur Reduktion der Leukozytenzahl in Platelet-rich Plasma und die Auswirkung auf die Proliferation von autologen mesenchymalen Stammzellen.

Preisträgerarbeit 1. Platz „Young Investigator Award“ der 30. Jahrestagung der Gesellschaft für Orthopädisch- Traumatologische Sportmedizin.

Sports Orthopaedics and Traumatology Sport-Orthopädie. 2016

- $\quad$ Loibl M, Lang S, Dendl LM, Nerlich M, Angele P, Gehmert S, Huber M. 
Leukocyte-Reduced Platelet-Rich Plasma Treatment of Basal Thumb Arthritis: A Pilot Study.

Biomed Res Int. 2016.

12.2. Originalarbeit 


\title{
Leukocyte-reduced platelet-rich plasma stimulates the in vitro proliferation of adipose-tissue derived mesenchymal stem cells depending on PDGF signaling
}

\author{
Siegmund Lang ${ }^{\mathrm{a}, *}$, Marietta Herrmann ${ }^{\mathrm{b}, \mathrm{c}}$, Christian Pfeifer ${ }^{\mathrm{a}}$, Gero Brockhoff ${ }^{\mathrm{d}}$, \\ Johannes Zellner ${ }^{\mathrm{a}}$, Michael Nerlich ${ }^{\mathrm{a}}$, Peter Angele ${ }^{\mathrm{a}}$, Lukas Prantl ${ }^{\mathrm{e}}$, \\ Sebastian Gehmert ${ }^{\mathrm{a}, \mathrm{e}, \mathrm{f}}$ and Markus Loibl ${ }^{\mathrm{a}}$ \\ ${ }^{a}$ Department of Trauma Surgery, University Medical Center Regensburg, Regensburg, Germany \\ ${ }^{\mathrm{b}}$ AO Research Institute, Davos, Switzerland \\ ${ }^{\mathrm{c}}$ IZKF Group Tissue Regeneration in Musculoskeletal Diseases, Orthopedic Center \\ for Musculoskeletal Research, University Würzburg, Würzburg, Germany \\ ${ }^{\mathrm{d}}$ Department of Obstetrics and Gynecology, University Medical Center Regensburg, \\ Regensburg, Germany \\ ${ }^{\mathrm{e}}$ Center of Plastic, Hand and Reconstructive Surgery, University Medical Center Regensburg, \\ Regensburg, Germany \\ ${ }^{\mathrm{f}}$ Department of Orthopedic Surgery, University Hospital Basel, Basel, Switzerland
}

\begin{abstract}
.
BACKGROUND: Platelet-rich Plasma (PRP) is suggested as xenoprotein-free cell-culture medium replacement for animalderived supplements.

OBJECTIVE: The aim of this study was to investigate PRP-triggered signaling in adipose derived mesenchymal stem cells (ASCs).

METHODS: PRP was obtained from 4 male patients. We incubated ASCs in $\alpha$-MEM with different Platelet derived growth factor (PDGF) subtypes or $10 \%$ or $20 \%$ pooled PRP or $20 \%$ fetal calf serum (FCS) prior to determination of the S-phase fraction (SPF). To investigate the influence of PDGF signaling on ASCs, PDGF receptor $\beta$ inhibitor was added, and protein expression of ASCs was measured.

RESULTS: ASCs exposed to $20 \%$ PRP, PDGF-AB and -BB demonstrated significant higher SPF in comparison to PDGF-AA and $20 \%$ FCS after 48 hours (all $P<0.05$ ). PDGF receptor $\beta$ inhibition diminished the PRP-induced SPF increase of ASCs significantly after 48 hours $(P<0.01)$. ASCs with PDGF receptor $\beta$ inhibition showed significant higher PDGF receptor $\beta$ and significant lower c-MYC expression compared to untreated cells in presence of $20 \%$ PRP after 48 hours (both $P<0.05$ ). CONCLUSIONS: The proliferation promoting effect of PRP on ASCs is mediated by PDGF signaling and is associated with c-MYC overexpression.
\end{abstract}

Keywords: Platelet-rich Plasma, mesenchymal stem cells, PDGF receptor $\beta$ inhibition, proliferation, cell culture

\footnotetext{
*Corresponding author: Siegmund Lang, Department of Trauma Surgery, University Hospital Regensburg, Franz-JosefStrauss-Allee 11, Regensburg, Germany. Tel.: +49 0941944 6842; E-mail: lang.siegmund@ gmail.com.
} 


\section{Introduction}

Mesenchymal stem cells (MSCs) are multipotent cells that can be easily harvested from adipose tissue (ASCs). They turned into a fundamental component in regenerative therapies due to their multilineage potential and their paracrine secretory ability [1-5]. For most clinical application, MSCs have to be isolated and expanded in vitro to purify the population and to gain higher cell numbers [6]. In many laboratory standard operating protocols (SOP) fetal calf serum (FCS) represents a medium supplement during cell expansion. Nevertheless, the immunological risks of using animal derived products for human application have to be considered [6-8]. Therefore, a growing number of studies suggests Platelet-rich Plasma (PRP) as a reasonable, xenoprotein-free medium additive [9-12]. PRP has been described as an autologous cocktail of growth factors and biomolecules, including platelet derived growth factor (PDGF), transforming growth factor beta (TGF- $\beta$ ) and vascular endothelial growth factor (VEGF). This cocktail is able to induce chemotactic, proliferative, angiogenic and anabolic cellular responses [12, 13]. Amongst others, PDGF is known to play a decisive role in the stimulation of MSC proliferation in vitro $[14,15]$. The PDGF family consists of four homodimers that include A-, B-, C-, or D-polypeptides and one heterodimeric AB-isoform [17]. They are interacting with PDGF receptor $\alpha$ and $\beta$ expressed on MCSs' surface [17]. Both receptors belong to the family of receptor protein tyrosine kinases [18], and can activate the same phosphoinositide 3 kinase (PI3K), Phospoinositol-Phospholipase C $\gamma$ (PLC $\gamma$ ), and mitogen activated protein kinase (MAPK) signaling pathway amongst others [19].

At present, we have limited information about the relationship between growth-factors in PRP and their promoting effect on the proliferation of MSCs, with particular attention to the cellular signaling cascades. As robust MSC expansion and differentiation are basic requirements in preclinical cell expansion, it becomes important to determine PRP induced cellular mechanisms that are determining the fate of MSCs. The identification of these mechanisms will contribute to establish PRP as a reliable medium supplement to grow MSCs for regenerative therapies in accordance with the requirements of good manufacturing practice (GMP) [20].

In previous studies we established a modified PRP preparation protocol for a commercially available PRP preparation kit to reduce the number of white blood cells in PRP [21]. We indicated a positive dose-dependent effect of leukocyte-reduced PRP as medium supplement on the proliferation of ASCs. Moreover, we identified several regulatory proteins in ASCs, whose expression was altered significantly in presence of PRP in comparison to FCS [22]. Ultimately, we identified PDGF receptor $\beta$ and c-MYC among the most significantly differentially regulated proteins.

The aim of the present study was to assess the role of PDGF signaling in ASC proliferation in PRP supplemented monolayer culture.

\section{Methods}

\subsection{Ethics statement}

The study was approved by the ethics committee of the University of Regensburg and written informed consent was obtained from each volunteer in accordance with the declaration of Helsinki prior to blood drawing and elective liposuction.

\subsection{PRP samples}

Venous blood $(15 \mathrm{ml})$ was drawn directly into the Arthrex Double Syringe (Arthrex, Inc., Naples, FL, USA) for the production of autologous conditioned plasma (ACP) using a winged infusion set 
(Sarstedt AG \& Co., Nümbrecht, Germany). The ACP double syringe was processed using a Hettich Rotofix 32a centrifuge at $1500 \mathrm{rpm}$ for 4 minutes with brake disabled as characterized previously [21]. With this settings an average platelet count of $548.5 \pm 104.9 \times 10^{3} / \mu 1$ in the plasma product can be achieved, while reducing the white blood cell count to $0.05 \pm 0.11 \times 10^{3} / \mu 1$, as shown before [21]. Blood was separated into two distinct layers by centrifugation whereas a plasma layer appeared on the top and the red/white blood cell layer was apparent on the bottom. The plasma containing the platelets (platelet rich plasma, PRP) was isolated by drawing the inner syringe according to the manufacturer's instructions. PRP samples were stored at $-20^{\circ} \mathrm{C}$ until they were pooled for further experiments $(n=4)$. As PRP was deep freezed right after centrifugation, no anticoagulant has been used. For the usage in the cell culture experiments PRP was activated by thawing.

\subsection{Adipose-tissue derived stem cell (ASC) isolation}

Human ASCs were isolated from solid subcutaneous adipose tissue, which was obtained from 4 patients undergoing elective body-contouring procedures, as described previously [21]. The samples were processed within 24 hours after harvesting. Briefly, subcutaneous fat tissue was washed in phosphate-buffered saline, and minced into pieces of $<2 \mathrm{~mm}^{3}$. Serum-free $\alpha$-MEM $(1 \mathrm{ml} / \mathrm{g}$ tissue $)$ and Liberase Blendzyme 3 (Roche Diagnostics, Rotkreuz, Switzerland) (2 U/g tissue) were added and incubated under continuous shaking at $37^{\circ} \mathrm{C}$ for 45 minutes. The digested tissue was sequentially filtered through $100-\mu \mathrm{m}$ and $40-\mu \mathrm{m}$ filters (Fisher Scientific GmbH, Schwerte, Germany) and centrifuged at $450 \mathrm{~g}$ for $10 \mathrm{~min}$. The supernatant was discarded and remaining cell pellet was washed twice with Hanks' balanced salt solution (Cellgro, Mediatech Inc. Manassas, VA, USA) and finally resuspended in $\alpha$-MEM growth medium containing 20\% FCS (Pan Biotech Gmbh, Aidenbach, Germany), 2 mM L-glutamine (Life technologies, Carlsbad, CA, USA), $100 \mathrm{U} / \mathrm{ml}$ penicillin, $100 \mathrm{~g} / \mathrm{ml}$ streptomycin (both Sigma-Aldrich, Saint Louis, MO, USA). Cells were plated at a density of $3 \times 10^{4} \mathrm{cells} / \mathrm{cm}^{2}$ in $175 \mathrm{~cm}^{2}$ cell culture flasks (Greiner Bio-One $\mathrm{GmbH}$, Frickenhausen, Germany) and incubated at $37^{\circ} \mathrm{C}$ in a humidified atmosphere containing $5 \% \mathrm{CO}_{2}$. All non-adherent cells were removed after 18 hours of incubation by washing culture dishes with Dulbecco's phosphate buffered saline (PBS, Sigma-Aldrich, St. Louis, MO, USA) and ASCs received fresh growth media every other day. For further experiments and analysis, $80 \%$ confluent cell layers of passage 0 were frozen in $90 \%$ FCS containing $10 \%$ dimethyl sulfoxide (DMSO, Invitrogen, Life Technologies GmbH, Darmstadt, Germany).

\subsection{Cell culture experiment with PRP}

$2.5 \times 10^{5}$ human ASCs at passage $1-2(n=4)$ were seeded in a $100 \mathrm{~mm}$ cell culture dish (Becton Dickinson and Company, Franklin Lakes, NJ, USA) and cultured in $7 \mathrm{ml}$ of $\alpha$-MEM supplemented with $20 \%$ FCS, $5 \mathrm{mM}$ glutamine and $100 \mathrm{U} / \mathrm{ml}$ penicillin with $100 \mathrm{~g} / \mathrm{ml}$ streptomycin for 48 hours. Afterwards, the medium was changed to serum-free $\alpha$-MEM and cells were incubated for 24 hours for cell cycle synchronization. The medium was replaced by $5 \mathrm{ml}$ media for all 6 experimental groups: Group 1: $\alpha$-MEM containing 20\% FCS, group 2: $\alpha$-MEM containing 20\% FCS with $10 \mathrm{ng} / \mathrm{ml}$ recombinant PDGF-AA, group 3: $\alpha$-MEM containing 20\% FCS with $10 \mathrm{ng} / \mathrm{ml} \mathrm{recombi-}$ nant PDGF-AB, group 4: $\alpha$-MEM containing $20 \%$ FCS with $10 \mathrm{ng} / \mathrm{ml}$ recombinant PDGF-BB, group 5: $\alpha$-MEM containing 10\% PRP, group 6: $\alpha$-MEM containing 20\% PRP. PRP from 4 volunteers was pooled and distributed according to the mentioned PRP concentrations. Control samples were taken right after synchronization (T0) and prepared for cell cycle analysis and Western Blot analysis (WB) as described below. Cells were incubated in corresponding medium for 6, 12, 24, 48 and 72 hours. Thereafter, the cells were harvested by trypsination for cell cycle analysis and Western Blot analysis. 


\subsection{Cell cycle analysis}

Cells were washed twice with ice-cold PBS containing 2\% FCS and incubated on ice overnight in $70 \%$ methanol. Afterwards, cells were washed twice with PBS and incubated in the presence of $10 \mu \mathrm{g} / \mathrm{ml}$ RNAse for 30 minutes at $37^{\circ} \mathrm{C}$. The DNA intercalating 4',6-Diamidin-2-phenylindol (DAPI) fluorochrome was added at final concentration of $1 \mu \mathrm{g} / \mathrm{ml} 15$ minutes prior to analysis to ensure quantitative DNA staining.

Flow cytometric analyses were performed on each sample with $3 \times 10^{5}$ DAPI stained cells using a FACSCanto-II flow cytometer (BD Biosciences, San Jose, CA, USA) equipped with a blue (488 nm), a red $(633 \mathrm{~nm})$, and a violet $(405 \mathrm{~nm})$ laser and standard optical configuration. The instrument was operated with the FACSDiva software Version 7.0 (BD Biosciences). The DNA dye DAPI was excited with the violet excitation line and fluorescence emission was detected by the optical trigon unit equipped with a 450/50 bp filter. DNA histograms were plotted on a linear scale upon cell doublet, aggregate, and debris discrimination via pulse processing. Cell cycle fractions (i.e. percentages of cells in G0/G1-, Sand G2/M-phase) were quantified using the ModFit LT 3.2 software (Verity Software House, Topsham, ME, USA). Treatment effects are expressed by the S-phase fraction (SPF) compared to untreated cells.

\subsection{Western blot analysis}

Cell culture media was removed and ASCs were washed twice in ice-cold PBS, and lysed in RIPA lysis buffer (Upstate, EMD Millipore Corporation, Temecula, CA, USA), including protease inhibitor cocktail (Roche Diagnostics, Mannheim, Germany) according to the manufacturer's instructions. The proteins were separated on SDS/PAGE gel and transferred to polyvinylidene difluoride membrane. The membrane was blocked with 5\% nonfat milk, and subsequently incubated with rabbit anti PDGF receptor beta antibody (ab32570, $1: 1000$ ), rabbit anti MEK-1 antibody (ab96379, $1: 2500)$, rabbit antic-MYC (ab32072, $1: 5000$ ), and mouse anti-GAPDH (ab8245, $1: 5000$ ) (all from Abcam, Cambridge, UK) for 1 hour at room temperature. Following incubation with goat anti-mouse IRDye 680 (LI-COR 926-68070, $1: 15000$ ) and goat anti-rabbit IRDye 800 (LI-COR 926-32211, $1: 15000$ ) secondary antibody, labeled proteins were detected using the LI-COR Odyssey detection system and the LI-COR Image Studio (LI-COR Biosciences, Lincoln, NV, USA).

\subsection{PDGF receptor $\beta$ Inhibition}

PDGF signaling was inhibited with CP-673451 (Selleck Chemicals, Houston, TX, USA), a selective PDGF receptor $\beta$ inhibitor. $2.5 \times 10^{5}$ human ASCs at passage $1-2(n=3)$ were seeded in a $100 \mathrm{~mm}$ cell culture dish and expanded for 48 hours as described above before starving for 24 hours in serum-free medium as described above. Afterwards, the medium was changed to $\alpha$-MEM with $3 \mu \mathrm{M}$ inhibitor and cells were incubated for 30 minutes at $37^{\circ} \mathrm{C}$ and $5 \% \mathrm{CO}_{2}$ prior to exchanging medium and incubation with $\alpha$-MEM containing: $20 \%$ FCS or $20 \%$ PRP. After 48 hours of incubation cells were harvested and prepared for cell cycle analysis and western blot as described above.

\subsection{Statistics}

Statistical analysis was performed using SPSS software package (version 19, IBM SPSS, Chicago, IL, USA) whereas all graphs were prepared by using GraphPad Prism (version 5, Statcon, La Jolla, CA, USA). All data were tested for normal distribution applying the Shapiro-Wilk test. Descriptive data are expressed in terms of mean \pm standard deviation (SD) as indicated. Differences between the SPF 
and protein expression of ASCs at different timepoints and in different cell culture conditions obtained by cell cycle analysis and by WB were investigated by One-Way Analysis of Variance (ANOVA) with Bonferroni correction. The paired $t$-test with Bonferroni correction was applied to identify significant differences between SPF and protein expression in ASCs treated with PDGF receptor $\beta$ inhibitor and without receptor inhibition. The level of significance was set at $P=0.05$ for all statistical tests.

\section{Results}

\subsection{Time dependent effect of PRP on ASC proliferation}

Flow cytometric analyses of ASCs revealed an increasing SPF in ASCs from $4.6 \pm 1.6 \%$ (T0), $4.4 \pm 2.8 \%$ at 6 hours and $3.6 \pm 1.3 \%$ at 12 hours, to the highest value at 24 hours $(21.8 \pm 12.0 \%)$ in the presence of $20 \%$ FCS (Fig. 1A). After 48 hours SPF decreased to $10.2 \pm 4.1 \%$ and to $8.1 \% \pm 3.2 \%$ after 72 hours. A similar course could be observed in the presence of $10 \%$ PRP (Fig. 1B): $3.2 \pm 0.7 \%$ to $4.0 \pm 1.9 \%$, to $33.9 \pm 12.4 \%$, to $7.0 \pm 2.7 \%$, to $5.8 \pm 1.3 \%$. In the presence of $20 \%$ PRP, the increase of the SPF after 24 hours was even more pronounced with $25.6 \pm 10.8 \%$. The highest SPF of $32.1 \pm 3.8 \%$ was detected after 48 hours, which dropped significantly to $5.8 \pm 0.7 \%$ after 72 hours $(P<0.01)$ (Fig. 1C). The highest SPF of ASCs was significantly increased after 48 hours in the presence of $20 \%$ PRP compared to $20 \%$ FCS and $10 \%$ PRP (both $P<0.01$ ) (Fig. 3).
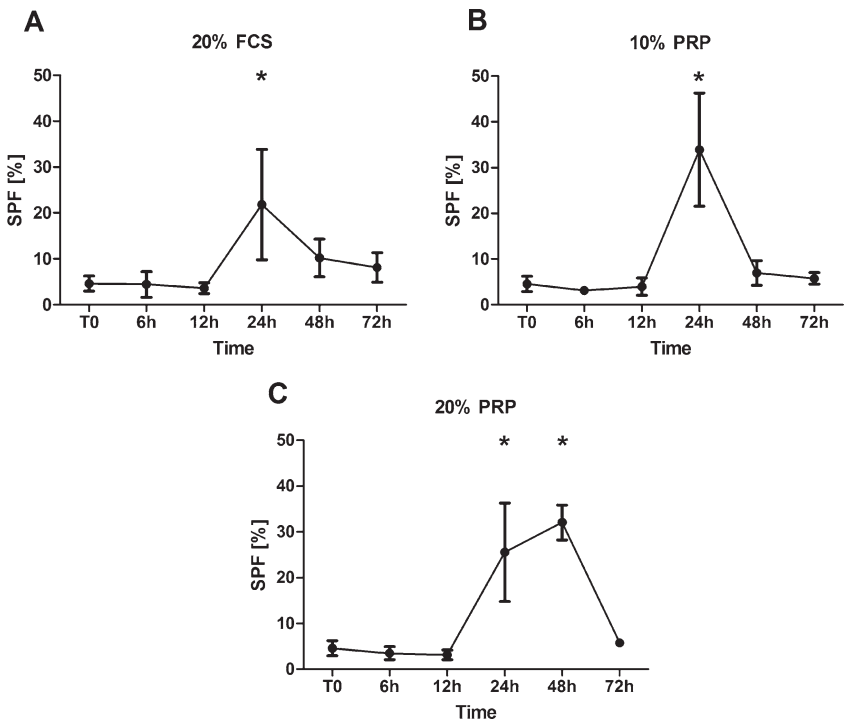

Fig. 1. Flow cytometric analyses of time-dependent proliferation of human ASCs under different media conditions. Flow cytometric analyses of S-Phase fraction (SPF) of human ASCs in the presence of $20 \%$ FCS (A), $10 \%$ PRP (B) and $20 \%$ $\mathrm{PRP}(\mathrm{C})$ as medium supplement over a period of 72 hours in cell culture. Values represent the mean \pm SD of 4 experiments $\left({ }^{*} P<0.05\right.$ as indicated). 


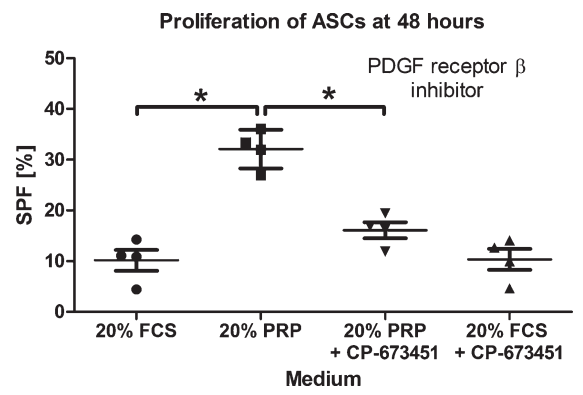

Fig. 2. Influence of PDGF receptor $\beta$ inhibition on the proliferation of human ASCs in flow cytometric analysis. Flow cytometric analyses of S-Phase fraction (SPF) of human ASCs in the presence of $20 \%$ FCS and $20 \%$ PRP, and additional PDGF receptor $\beta$ inhibition $(\mathrm{CP}-673451)$ at 48 hours. Values represent the mean $\pm \mathrm{SD}$ of 4 experiments $\left({ }^{*} P<0.05\right.$ as indicated).

\subsection{PRP stimulates ASC proliferation depending on signaling via PDGF receptor $\beta$}

Cell cycle analysis of the SPF of ASCs revealed a significant higher percentage of cells in the SPhase in the presence of $20 \%$ PRP in comparison to $20 \%$ FCS $(P<0.01)$ after 48 hours, with an SPF of $32.1 \pm 3.8 \%$ and $10.2 \pm 4.1 \%$, respectively (Fig. 2).

Additional PDGF receptor $\beta$ inhibition resulted in similar SPFs of $16.1 \pm 3.1 \%$ in the presence of $20 \%$ PRP in comparison to $10.4 \pm 4.2 \%$ in the presence of $20 \%$ FCS after 48 hours. Moreover, PDGF receptor $\beta$ inhibition revealed a significant reduction in the SPF of ASCs in 20\% PRP supplemented medium $(P<0.01)$ (Fig. 2). In contrast, similar SPFs of ASCs were found in $20 \%$ FCS supplemented medium with and without PDGF receptor $\beta$ inhibitor.

\subsection{PDGF subtypes $-A B$ and $-B B$ stimulate ASC proliferation}

Flow cytometric analyses of ASCs revealed similar SPF in ASCs in the presence of $20 \%$ FCS and further supplementation of $10 \mathrm{ng}$ PDGF -AA after 48 hours $(9.0 \pm 1.3 \%)$. SPF of ASCs supplemented with $10 \mathrm{ng}$ PDGF -AB $(17.0 \pm 3.5 \%)$ was significantly higher than the SPF of cells with $10 \mathrm{ng}$ PDGF -AA supplement $(P<0.05)$ (Fig. 3). Addition of $10 \mathrm{ng}$ PDGF -BB resulted in a significantly higher $\mathrm{SPF}$ of $22.0 \pm 5.1 \%$ in comparison to $10 \mathrm{ng}$ PDGF -AA after 48 hours $(P<0.01)$ (Fig. 3). No difference between the SPF of ASC cultured with $10 \mathrm{ng}$ PDGF -BB and $10 \mathrm{ng}$ PDGF -AB supplement was detected after 48 hours (Fig. 3). There was no significant difference between the SPF of ASCs in the presence of $10 \mathrm{ng}$ PDGF-BB $(22.0 \pm 5.1 \%)$ and $20 \mathrm{ng}$ PDGF-BB $(22.0 \pm 1.9 \%)(P=0.21)$ (data not shown). The highest SPF was found in ASCs cultured with 20\% PRP supplemented medium in comparison to the SPF of cells in presence of all other supplements respectively $(32.1 \pm 3.8 \%$, all $P<0.05)$ (Fig. 3).

\subsection{Time dependent expression of PDGF receptor $\beta, c-M Y C$, and $M E K-1$}

Western blot analysis of PDGF receptor $\beta$ expression in ASCs revealed a peak after 12 hours when cultured in $\alpha$-MEM containing $20 \%$ FCS $(P<0.05)$ (Fig. 4A). In cells cultured in the presence of $10 \%$ or $20 \%$ PRP, the PDGF receptor $\beta$ expression decreased significantly after 6 hours (both 
Proliferation of ASCs at $\mathbf{4 8}$ hours

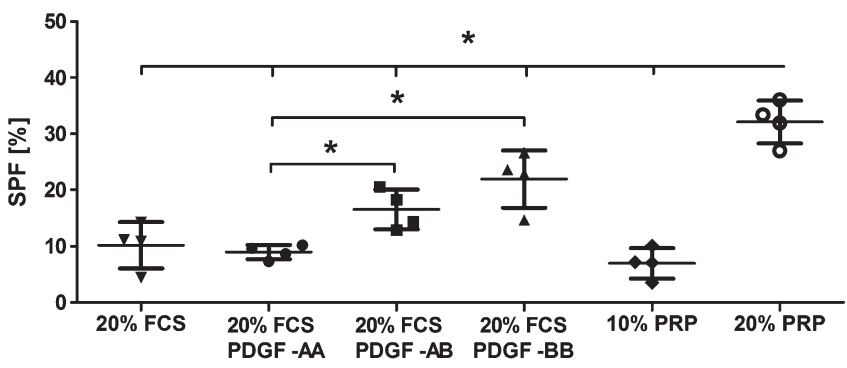

Medium

Fig. 3. Proliferation of human ASCs after 48 hours under different media conditions. Flow cytometric analyses of S-Phase fraction (SPF) of human ASCs in the presence of $20 \%$ FCS and 10 ng recombinant PDGF subtypes -AA, -AB and -BB, $10 \% \mathrm{PRP}$ and $20 \% \mathrm{PRP}$ as medium supplement at 48 hours. Values represent the mean $\pm \mathrm{SD}$ of 4 experiments $\left({ }^{*} P<0.05\right.$ as indicated).

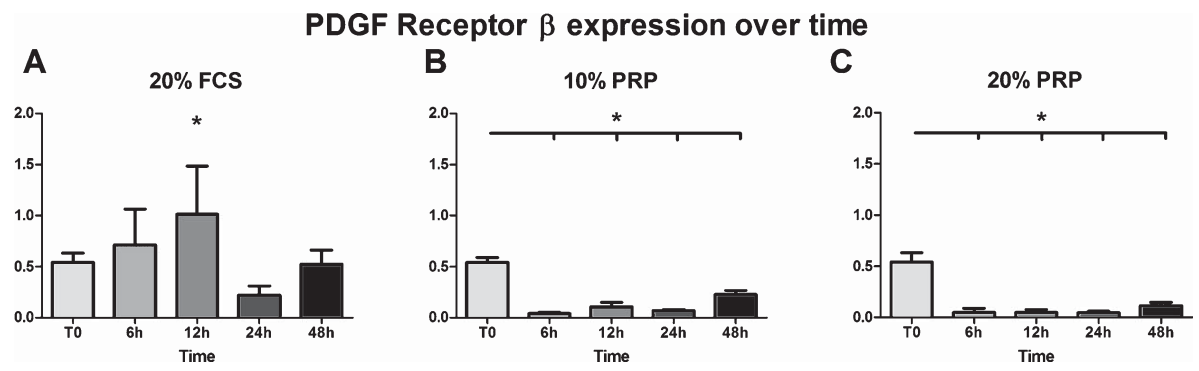

Fig. 4. Western blot analysis of PDGF receptor $\beta$ expression in ASCs. Western blot analysis of PDGF receptor $\beta$ expression in ASCs right after starving (T0), at 6, 12, 24 and 48 hours of incubation: ASCs at passage 3 or below were cultured in $\alpha$-MEM containing $20 \%$ FCS (A), $10 \%$ PRP (B) and $20 \%$ PRP (C). Values represent the mean \pm SD of 4 experiments $\left({ }^{*} P<0.05\right.$ as indicated).

$P<0.01)$ and remained at a low level at all time-points in comparison to baseline T0 (all $P>0.05$ ) (Fig. 4B and C).

C-MYC expression in ASCs cultured in $\alpha$-MEM containing 20\% FCS also demonstrated a significant peak after 12 hours compared to baseline T0 $(P<0.05)$ (Fig. 5A). Whereas $10 \%$ and $20 \%$ PRP media supplementation induced a significant peak of c-MYC expression after 48 hours compared to all previous time points (all $P<0.05$ ) (Fig. 5B and C). Furthermore, c-MYC expression of ASCs treated with $20 \%$ PRP substituted medium was significantly higher in comparison to $10 \%$ PRP after 48 hours $(P<0.01)$ (data not shown).

MEK1 expression of ASCs cultured in $\alpha$-MEM containing 20\% FCS peaked after 24 hours of incubation $(P<0.01)$ (supplementary material 1A), whereas MEK1 expression peaked after 6 hours in presence of $10 \%$ PRP $(P<0.01)$ (supplementary material 1B). However, similar MEK1 expression was observed in ASCs cultured in the presence of $20 \% \mathrm{PRP}$ at every time point respectively (all $P>0.05$ ) (supplementary material 1C). 
c-MYC expression over time

A

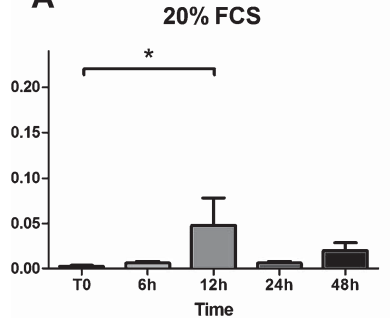

B

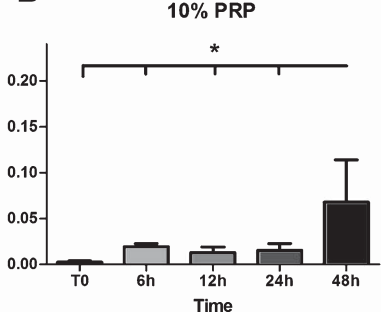

C

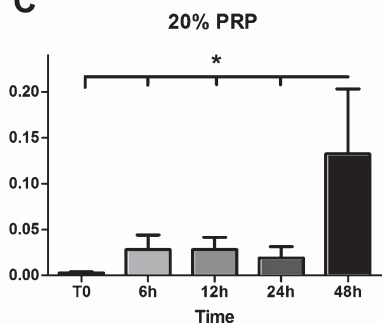

Fig. 5. Western blot analysis of c-MYC expression in ASCs. Western blot analysis of c-MYC expression in ASCs right after starving (T0), at $6,12,24$ and 48 hours of incubation: ASCs at passage 3 or below were cultured in $\alpha$-MEM containing $20 \%$ FCS (A), $10 \%$ PRP (B) and $20 \%$ PRP (C). Values represent the mean \pm SD of 4 experiments $\left({ }^{*} P<0.05\right.$ as indicated).

PDGFR $\beta$ expression in ASCs after 48 hours

A

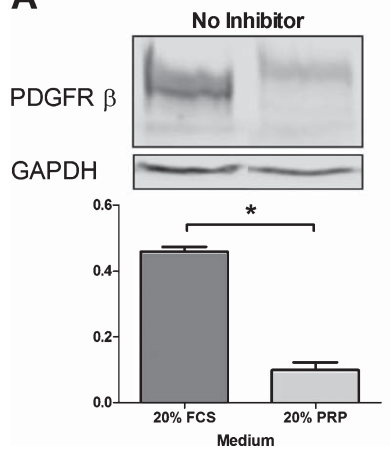

B

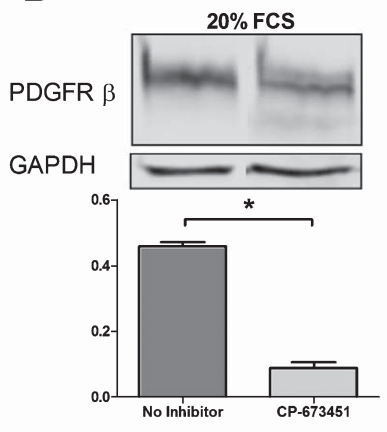

C

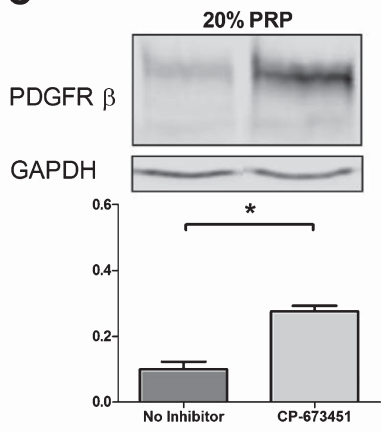

Fig. 6. PDGF Receptor $\beta$ expression in ASCs after PDGF Receptor $\beta$ inhibition. Western blot analysis of PDGF Receptor $\beta$ (PDGFR $\beta$ ) expression in ASCs after $48 \mathrm{~h}$ : ASCs below passage 3 were cultured in $\alpha$-MEM containing $20 \%$ FCS and $20 \%$ PRP with or without PDGF receptor $\beta$ inhibitor (CP-673451) for 48 hours. GAPDH was used as a housekeeping gene. Values represent the mean $\pm \mathrm{SD}$ of 3 experiments $\left({ }^{*} P<0.05\right.$ as indicated).

\subsection{Influence of PDGF receptor $\beta$ inhibition on protein expression in ASCs after 48 hours}

PDGF receptor $\beta$ expression was significantly lower in ASCs cultured for 48 hours in the presence of $20 \%$ PRP $(0.10 \pm 0.02)$ in comparison to $20 \%$ FCS $(0.46 \pm 0.01)(P<0.01)$ (Fig. 6A). Inhibition of PDGF receptor $\beta$ induced a significant decrease in the expression of PDGF receptor $\beta$ in the presence of $20 \%$ FCS (to $0.09 \pm 0.02, P<0.01$ ) (Fig. 6B). On the contrary, inhibition of PDGF receptor $\beta$ induced a significant increase in the expression of PDGF receptor $\beta$ in the presence of $20 \%$ PRP $(0.28 \pm 0.02$, $P<0.05$ ) (Fig. 6C).

C-MYC expression was significantly higher in ASCs cultured for 48 hours in the presence of $20 \%$ $\operatorname{PRP}(0.16 \pm 0.04)$ in comparison to $20 \%$ FCS $(0.03 \pm 0.01, P<0.05)$ (Fig. 7A). Inhibition of PDGF 


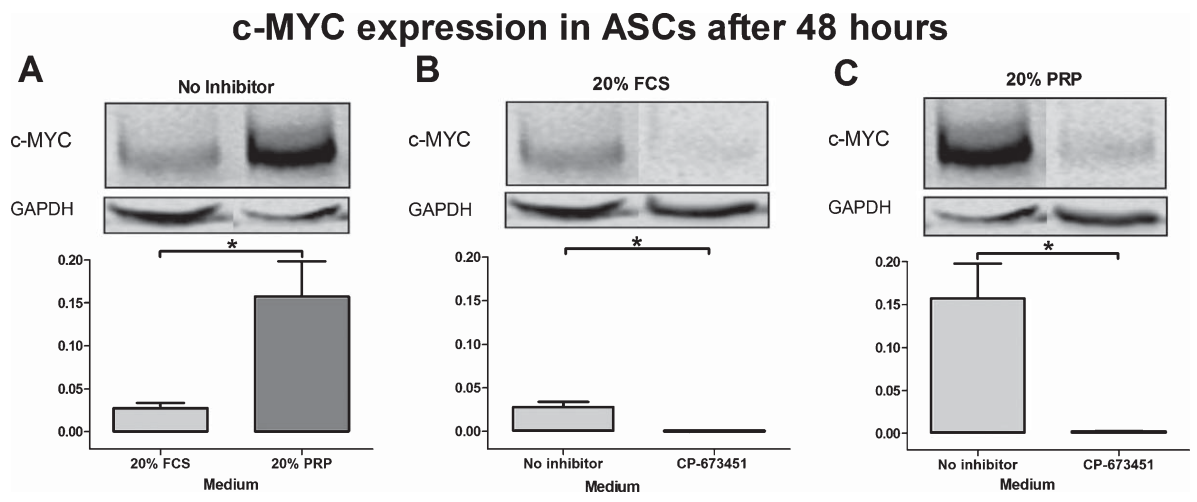

Fig. 7. C-MYC expression in ASCs after PDGF Receptor $\beta$ inhibition. Western blot analysis of C-MYC expression in ASCs after $48 \mathrm{~h}$ : ASCs below passage 3 were cultured in $\alpha$-MEM containing $20 \%$ FCS and $20 \%$ PRP with or without PDGF receptor $\beta$ inhibitor (CP-673451) for 48 hours. Values represent the mean $\pm \mathrm{SD}$ of 3 experiments $\left({ }^{*} P<0.05\right.$ as indicated).

receptor $\beta$ induced a significant reduction of c-MYC expression of ASCs in the presence of $20 \%$ FCS $(0.0003 \pm 0.0006)$ and $20 \%$ PRP $(0.002 \pm 0.001)$ (both $P<0.05)$ (Fig. 7B and C).

MEK1 expression was similar in ASCs in the presence of $20 \%$ FCS $(0.45 \pm 0.05)$ and $20 \%$ PRP $(0.60 \pm 0.05)$ after 48 hours $(P=0.05)$ (supplementary material $2 \mathrm{~A})$. Inhibition of PDGF receptor $\beta$ did not induce changes of expression levels of MEK1 in the presence of $20 \%$ FCS $(0.31 \pm 0.02)$ or $20 \%$ PRP $(0.53 \pm 0.13)$ (both $P>0.05)$ (supplementary material $2 \mathrm{~B}$ and $\mathrm{C}$ ).

\section{Discussion}

As suggested by our previous work [20,21], we found a significant increase in proliferation of ASCs when incubated in presence of $20 \%$ PRP supplementation in comparison to $20 \%$ FCS. Here we prove for the first time that this effect is mediated by PDGF signaling, supported by the findings of PDGF receptor $\beta$ inhibition in PRP cultures, and conversely the supplementation of FCS cultures with recombinant PDGF isoforms. Furthermore, we show a correlation between c-MYC-expression and ASCs proliferation in presence of $20 \%$ PRP.

Animal derived cell culture supplements bear the risk of contamination, immunogenicity or change in MSC gene expression level [19, 22-24]. PRP has been proposed as a potential autologous alternative to xenogenic media supplements, or human allogenic supplements, that often reveal the limitation of suboptimal rate of cell proliferation [25]. The stimulatory effect of PRP on the proliferation of MSCs has been reported before [25-27]. Taking various PRP preparations into account, it becomes crucial to describe the biological characteristics prior to development of reproducible in vivo or in vitro applications [28]. In a previous study, we characterized the biological composition of the applied leukocyte-poor PRP in detail [21]. We also proofed an unique change in the proteomic profile of ASCs in presence of PRP [22].

Van Pham et al. showed an elevated proliferation curve of ASCs when treated with PRP supplemented medium in comparison to FCS over a period of 105 hours. After 24 hours, ASCs began to proliferate significantly faster in presence of PRP [29]. In the present study, we illustrated a promoting effect of $20 \%$ PRP cell culture medium supplement on ASC proliferation after 24 to 48 hours of incubation. This effect peaked after 48 hours, and exceeded standard cell culture medium containing $20 \%$ FCS by far, 
even if recombinant PDGF subtypes -AA or -AB were added. In contrast to Van Pham et al., 20\% PRP did not show a proliferation promoting effect on ASCs beyond 48 hours of incubation. Consequently, this implies the need for medium replacement every 3 days in our autologous cell culture setting utilizing 20\% PRP as medium supplement. However, considerable cell confluency in our setting might have contributed to contact inhibition of ASCs at this time.

It has been suggested, that PRP promotes the proliferation of ASCs mainly via activation of PDGFR/AKT pathway [10], which is in line with the findings of this manuscript. Our proliferation analysis results further implicate, that PDGF subtypes -AB and -BB are effective in increasing ASCs proliferation comparable to the PPR effect and exceeding the effect of the subtype AA. Relevant in vivo PDGF-PDGF receptor interactions are those of PDGF -AA and PDGF -CC via PDGFR $\alpha$, and PDGF -BB via PDGF receptor $\beta$ [19]. Additional to the results of FCS culture supplementation with recombinant PDGF isoforms we highlighted the importance of PDGF receptor $\beta$ signaling for the proliferation promoting effect of PRP on ASCs by inhibition of PDGF receptor $\beta$. Gharibi et al. described the regulation of proliferation and differentiation of MSCs under influence of PDGF -BB in detail. Their results implicate that PDGF receptor $\beta$ signaling in MSCs simultaneously activates PI3K/AKT/mTOR and ERK signaling as mediator of differentiation [30]. ERK-signaling was described as an inhibitor of MSC differentiation by blocking PPAR $\gamma$ and CEBP $\alpha$ expression, whereas $\mathrm{PI} 3 \mathrm{~K} / \mathrm{AKT}$ signaling was found to be the main contributor in promoting MSC cell cycle progression [30]. Moreover, a negative feedback mechanism between PI3K/AKT and PDGF receptor $\beta$ expression has been demonstrated [30]. This is consistent with our results describing the inverse relationship between cell proliferation and PDGF receptor $\beta$ expression in PRP cultured ASCs. Adding PDGF receptor $\beta$ inhibitor significantly diminished cell proliferation in presence of PRP after 48 hours. In addition, we provide information about protein expression kinetics: The influence of $20 \%$ PRP lead to a significantly, ongoing decline of PDGF receptor $\beta$ expression for at least 72 hours, which apparently has been initiated during the first 6 hours of incubation. It can be assumed, that the subsequent down regulation of PDGF receptor $\beta$ in PRP-stimulated ASCs is based on the well described effect of receptor complex internalization into endosomes induced by ligand binding [31]. Growth factor triggered PDGF receptor $\beta$ downregulation is a possible explanation for high PRP concentrations (e.g. 60\%) having a minor impact, or even an inhibitory effect on the proliferation of different cell types, than lower concentrations (e.g. 20\%) [10, 31-33]. Nevertheless, in a previous study we found $20 \%$ PRP medium supplementation results in a higher proliferation promoting effect on ASCs than 10\% PRP [22]. In summary, these results illustrate the importance of PDGF receptor $\beta$ activation and PI3K/AKT signaling with a negative feedback regulation on PDGF receptor $\beta$ expression for the proliferation of MSCs cultured in PRP. Thus in line we demonstrated that the PDGF subtypes $-\mathrm{AB}$ and $-\mathrm{BB}$ in PRP are the main mediators of the proliferation stimulating effect on ASCs.

The nuclear transcriptional factor c-MYC is a key mediator of PDGF-induced mitogenesis [34]. C-MYC transmits proliferative signals, regulates cellular growth by transversing into $\mathrm{S}$ phase of the cell cycle and is involved in differentiation [35-37]. Stimulated proliferation of ASCs cultured in $20 \%$ PRP substituted medium was attributed to c-MYC over-expression in our study. The results of the PDGF receptor $\beta$ inhibition experiments emphasize the dependency of ASC proliferation from c-MYC overexpression in presence of PRP. Jones et al. suggested that there is a common signaling cascade, by which mitogens drive arrested cells into the cell cycle involving the input of c-MYC, PI3K and MEK [38]. However, we were not able to detect a significant influence of PRP medium supplementation or PDGF receptor $\beta$ inhibition on MEK1 expression in ASCs.

Noteworthy, overexpression of the oncoprotein c-MYC is also correlated with tumorigenesis and could lead to spontaneous transformation in MSCs [38-40]. Assessing this major risk for the clinical application, a first study indicated a good resistance of ASCs to spontaneous transformation during 
in vitro expansion in the presence of pooled allogeneic human serum, despite high c-MYC protein expression associated with enhanced proliferation rates [41]. For clinical preparation of ASCs, extensive proliferation on the one hand and differentiation on the other hand is necessary. It has been shown that enforced c-MYC overexpression blocks terminal cell differentiation in different cell types [41-43]. Interestingly, a reduced adipogenic differentiation capacity of ASCs cultured with PRP associated with PPAR $\gamma$ downregulation has recently been described by Amable et al. [44]. However, the influence of c-MYC overexpression on ASC differentiation in PRP supplemented medium remains to be described in detail.

These results taken together show clearly that c-MYC is an important mediator for ASC proliferation and differentiation.

The knowledge about PRP-triggered mechanisms that direct ASCs' fate is a key to tissue engineering approaches, and crucial to meet GMP requirements for autologous cell culture settings. Adjusted growth factor concentrations in PRP are necessary for gaining optimal proliferation rates of ASCs. Considering paradoxical inhibitory effects of high growth factor concentrations, the "more is better" attitude of many PPR preparations $[13,44,45]$ has to be questioned. This study highlights that PRP as culture medium supplement in ASC expansion is depending on PDGF receptor $\beta$ signaling and provides robust ASC proliferation in a time dependent manner. Our findings identified c-MYC as an important PDGF receptor $\beta$ downstream effector protein, mediating cell cycle progress and proliferation of ASCs in presence of PRP for the first time. The results of the present study advocated that PDGF plays the leading role in triggering the mitogenic signal-transduction leading to ASC proliferation.

\section{Conclusion}

PRP-induced PDGF signaling plays a decisive role in the stimulation of proliferation of ASCs, and regulates the protein expression over time. PRP can be considered a highly effective substitute for allogenic cell culture medium supplement. 20\% PRP culture needs medium replacement every 3 days. $\mathrm{C}-\mathrm{MYC}$ is a key-meditator of ASC proliferation in the presence of PRP, however its' distinct role has to be further evaluated with special regard to the influence on ASC differentiation.

\section{Limitations of this study}

Several limitations of this study need to be noted: First, PRP samples were stored at $-20{ }^{\circ} \mathrm{C}$ prior to cell culture experiments. Damage to platelets during storing could lead to activation of the platelets with subsequent release of growth factors $[46,47]$. Therefore, the obtained data may not correctly mimic in vivo environment. Second, cell culture experiments were not performed with autologous PRP. However, all data originated from the same samples. Third, the low sample size of this study has to be considered, when interpreting the results. Last, the biological characteristics of the leukocyte-reduced PRP used in the present study have been described in detail previously [21], however it represents only one out of many PRP preparations available.

\section{Acknowledgments}

The authors would like to thank Elke Gerstl for the support with all experiments. We would like to acknowledge Arthrex Inc. (Naples, FL, USA) for contributing to the sampling material. 


\section{Competing Interests}

Peter Angele is an expert advisor for Arthrex Inc. (Naples, FL, USA). All other authors declare that there is no conflict of interests regarding the publication of this paper.

\section{Supplementary material}

The supplementary material is available in the electronic version of this article: http://dx.doi.org/ 10.3233/CH-170246.

\section{References}

[1] P. Bianco, P.G. Robey and P.J. Simmons, Mesenchymal stem cells: Revisiting history, concepts, and assays, Cell Stem Cell 2 (2008), 313-319. doi:10.1016/j.stem.2008.03.002

[2] P.A. Zuk, M. Zhu, H. Mizuno, J. Huang, J.W. Futrell, A.J. Katz, et al., Multilineage cells from human adipose tissue: Implications for cell-based therapies, Tissue Eng 7 (2001), 211-228. doi:10.1089/107632701300062859

[3] S.T.-F. Hsiao, A. Asgari, Z. Lokmic, R. Sinclair, G.J. Dusting, S.Y. Lim, et al., Comparative analysis of paracrine factor expression in human adult mesenchymal stem cells derived from bone marrow, adipose, and dermal tissue, Stem Cells Dev 21 (2012), 2189-2203. doi:10.1089/scd.2011.0674

[4] S. Sadat, S. Gehmert, Y-H Song, Y. Yen, X. Bai, S. Gaiser, et al., The cardioprotective effect of mesenchymal stem cells is mediated by IGF-I and VEGF, Biochemical and Biophysical Research Communications 363 (2007), 674-679. doi:10.1016/j.bbrc.2007.09.058

[5] J.-F. Stoltz, D. Bensoussan, N. De Isla, L. Zhang, Z. Han, J. Magdalou, et al., Stem cells and vascular regenerative medicine: A mini review, Clin Hemorheol Microcirc 64 (2016), 613-633. doi:10.3233/CH-168036

[6] S.R. Coleman, Structural fat grafting: More than a permanent filler, Plast Reconstr Surg 118 (2006), 108S-20S. doi:10.1097/01.prs.0000234610.81672.e7

[7] T.A. Selvaggi, R.E. Walker and T.A. Fleisher, Development of antibodies to fetal calf serum with arthus-like reactions in human immunodeficiency virus-infected patients given syngeneic lymphocyte infusions, Blood 89 (1997), 776-779.

[8] J.L. Spees, C.A. Gregory, H. Singh, H.A. Tucker, A. Peister, P.J. Lynch, et al., Internalized antigens must be removed to prepare hypoimmunogenic mesenchymal stem cells for cell and gene therapy, Mol Ther 9 (2004), 747-756. doi:10.1016/j.ymthe.2004.02.012

[9] A. Kocaoemer, S. Kern, H. Klüter and K. Bieback, Human AB serum and thrombin-activated platelet-rich plasma are suitable alternatives to fetal calf serum for the expansion of mesenchymal stem cells from adipose tissue, Stem Cells $\mathbf{2 5}$ (2007), 1270-1278. doi:10.1634/stemcells.2006-0627

[10] L.A. Tchang, B.E. Pippenger, A. Todorov, F. Wolf, M.G. Burger, C. Jaquiery, et al., Pooled thrombin-activated plateletrich plasma: A substitute for fetal bovine serum in the engineering of osteogenic/vasculogenic grafts: PRP as a substitute for FBS in engineering vascularized bone grafts, Journal of Tissue Engineering and Regenerative Medicine (2015). doi:10.1002/term.2054

[11] F. Atashi, M.E.E. Jaconi, B. Pittet-Cuénod and A. Modarressi, Autologous PLATELET-RICH Plasma: A biological supplement to enhance adipose-derived mesenchymal stem cell expansion, Tissue Engineering Part C: Methods 21 (2014), 253-262. doi:10.1089/ten.tec.2014.0206

[12] T. Hatlapatka, P. Moretti, A. Lavrentieva, R. Hass, N. Marquardt, R. Jacobs, et al., Optimization of culture conditions for the expansion of umbilical cord-derived mesenchymal stem or stromal cell-like cells using xeno-free culture conditions, Tissue Eng Part C Methods 17 (2011), 485-493. doi:10.1089/ten.tec.2014.0206

[13] B.L. Eppley, J.E. Woodell and J. Higgins, Platelet quantification and growth factor analysis from platelet-rich plasma: Implications for wound healing, Plast Reconstr Surg 114 (2004), 1502-1508.

[14] A.D. Mazzocca, M.B.R. McCarthy, D.M. Chowaniec, E.M. Dugdale, D. Hansen, M.P. Cote, et al., The positive effects of different platelet-rich plasma methods on human muscle, bone, and tendon cells, The American Journal of Sports Medicine 40 (2012), 1742-1749. doi:10.1177/0363546512452713

[15] F. Ng, S. Boucher, S. Koh, K.S.R. Sastry, L. Chase, U. Lakshmipathy, et al., PDGF, TGF-, and FGF signaling is important for differentiation and growth of mesenchymal stem cells (MSCs): Transcriptional profiling can identify markers and signaling pathways important in differentiation of MSCs into adipogenic, chondrogenic, and osteogenic lineages, Blood 112 (2008), 295-307. doi:10.1182/blood-2007-07-103697 
[16] N. Fekete, M.T. Rojewski, R. Lotfi and H. Schrezenmeier, Essential components for ex vivo proliferation of mesenchymal stromal cells, Tissue Eng Part C Methods 20 (2014), 129-139. doi:10.1089/ten.TEC.2013.0061

[17] L. Fredriksson, H. Li and U. Eriksson, The PDGF family: Four gene products form five dimeric isoforms, Cytokine \& Growth Factor Reviews 15 (2004), 197-204. doi:10.1016/j.cytogfr.2004.03.007

[18] M.A. Lemmon and J. Schlessinger, Cell signaling by receptor tyrosine kinases, Cell 141 (2010), 1117-1134. doi:10.1016/j.cell.2010.06.011

[19] J. Andrae, R. Gallini and C. Betsholtz, Role of platelet-derived growth factors in physiology and medicine, Genes Dev 22 (2008), 1276-1312. doi:10.1101/gad.1653708

[20] C. Unger, H. Skottman, P. Blomberg, M.S. Dilber and O. Hovatta, Good manufacturing practice and clinical-grade human embryonic stem cell lines, Hum Mol Genet 17 (2008), R48-R53. doi:10.1093/hmg/ddn079

[21] M. Loibl, S. Lang, G. Brockhoff, B. Gueorguiev, F. Hilber, M. Worlicek, et al., The effect of leukocyte-reduced platelet-rich plasma on the proliferation of autologous adipose-tissue derived mesenchymal stem cells, Clin Hemorheol Microcirc (2014). doi:10.3233/CH-141920

[22] M. Loibl, S. Lang, A. Hanke, M. Herrmann, M. Huber, G. Brockhoff, et al., Leukocyte-reduced platelet-rich plasma alters protein expression of adipose-tissue derived mesenchymal stem cells, Accepted Plastic and Reconstructive Surgery (2016).

[23] L. Sensebé, M. Krampera, H. Schrezenmeier, P. Bourin and R. Giordano, Mesenchymal stem cells for clinical application, Vox Sang 98 (2010), 93-107. doi:10.1111/j.1423-0410.2009.01227.x

[24] K. Bieback, V.A.-T. Ha, A. Hecker, M. Grassl, S. Kinzebach, H. Solz, et al., Altered gene expression in human adipose stem cells cultured with fetal bovine serum compared to human supplements, Tissue Eng Part A 16 (2010), 3467-3484. doi:10.1089/ten.TEA.2009.0727

[25] K. Bieback, A. Hecker, A. Kocaömer, H. Lannert, K. Schallmoser, D. Strunk, et al., Human alternatives to fetal bovine serum for the expansion of mesenchymal stromal cells from bone marrow, Stem Cells 27 (2009), $2331-2341$. doi:10.1002/stem.139

[26] H.S. Cho, I.H. Song, S.-Y. Park, M.C. Sung, M.-W. Ahn and K.E. Song, Individual variation in growth factor concentrations in platelet-rich plasma and its influence on human mesenchymal stem cells, Korean J Lab Med 31 (2011), 212-218. doi:10.3343/kjlm.2011.31.3.212

[27] N. Kakudo, T. Minakata, T. Mitsui, S. Kushida, F.Z. Notodihardjo and K. Kusumoto, Proliferation-promoting effect of platelet-rich plasma on human adipose-derived stem cells and human dermal fibroblasts, Plast Reconstr Surg 122 (2008), 1352-1360. doi:10.1097/PRS.0b013e3181882046

[28] T.N. Castillo, M.A. Pouliot, H.J. Kim and J.L. Dragoo, Comparison of growth factor and platelet concentration from commercial platelet-rich plasma separation systems, The American Journal of Sports Medicine 39 (2010), $266-271$. doi:10.1177/0363546510387517

[29] P. Van Pham, N.B. Vu, N.L.-C. Phan, D.M. Le, N.C. Truong, N.H. Truong, et al., Good manufacturing practicecompliant isolation and culture of human adipose derived stem cells, Biomedical Research and Therapy (2014), 1. doi:10.7603/s40730-014-0021-6

[30] B. Gharibi, M.S. Ghuman and F.J. Hughes, Akt- and Erk-mediated regulation of proliferation and differentiation during PDGFR $\beta$-induced MSC self-renewal, J Cell Mol Med 16 (2012), 2789-2801. doi:10.1111/j.1582-4934.2012. 01602.x

[31] A. Sorkin, B. Westermark, C-H Heldin and L. Claesson-Welsh, Effect of receptor kinase inactivation on the rate of internalization and degradation of PDGF and the PDGF beta-receptor, The Journal of Cell Biology 112 (1991), 469-478.

[32] G. Weibrich, T. Hansen, W. Kleis, R. Buch and W.E. Hitzler, Effect of platelet concentration in platelet-rich plasma on peri-implant bone regeneration, Bone 34 (2004), 665-671. doi:10.1016/j.bone.2003.12.010

[33] F. Graziani, S. Ivanovski, S. Cei, F. Ducci, M. Tonetti and M. Gabriele, The in vitro effect of different PRP concentrations on osteoblasts and fibroblasts, Clin Oral Implants Res 17 (2006), 212-219. doi:10.1111/j.1600-0501.2005.01203.x

[34] T. Bowman, M.A. Broome, D. Sinibaldi, W. Wharton, W.J. Pledger, J.M. Sedivy, et al., Stat3-mediated Myc expression is required for Src transformation and PDGF-induced mitogenesis, Proc Natl Acad Sci U S A 98 (2001), 7319-7324. doi:10.1073/pnas.131568898

[35] S.-C. Choi, S.-J. Kim, J.-H. Choi, C.-Y. Park, W.-J. Shim and D.-S. Lim, Fibroblast growth factor-2 and -4 promote the proliferation of bone marrow mesenchymal stem cells by the activation of the PI3K-Akt and ERK1/2 signaling pathways, Stem Cells Dev 17 (2008), 725-736. doi:10.1089/scd.2007.0230

[36] M. Henriksson, A. Bakardjiev, G. Klein and B. Lüscher, Phosphorylation sites mapping in the N-terminal domain of c-myc modulate its transforming potential, Oncogene 8 (1993), 3199-3209.

[37] R. Heikkila, G. Schwab, E. Wickstrom, S.L. Loke, D.H. Pluznik, R. Watt, et al., A c-myc antisense oligodeoxynucleotide inhibits entry into S phase but not progress from G0 to G1, Nature 328 (1987), 445-449. doi:10.1038/328445a0 
[38] S.M. Jones and A. Kazlauskas, Growth-factor-dependent mitogenesis requires two distinct phases of signalling, Nat Cell Biol 3 (2001), 165-172. doi:10.1038/35055073

[39] K.A. O’Donnell, D. Yu, K.I. Zeller, J.-W. Kim, F. Racke, A. Thomas-Tikhonenko, et al., Activation of transferrin receptor 1 by c-Myc enhances cellular proliferation and tumorigenesis, Mol Cell Biol 26 (2006), $2373-2386$. doi:10.1128/MCB.26.6.2373-2386.2006

[40] D. Rubio, S. Garcia, M.F. Paz, T. De la Cueva, L.A. Lopez-Fernandez, A.C. Lloyd, et al., Molecular characterization of spontaneous mesenchymal stem cell transformation, PLOS ONE 3 (2008), e1398. doi:10.1371/journal.pone.0001398

[41] A.C. Paula, T.M. Martins, A. Zonari, S.P. Frade, P.C. Angelo, D.A. Gomes, et al. Human adipose tissue-derived stem cells cultured in xeno-free culture condition enhance c-MYC expression increasing proliferation but bypassing spontaneous cell transformation, Stem Cell Research \& Therapy (2015), 6. doi:10.1186/s13287-015-0030-4

[42] J.A. Coppola and M.D. Cole, Constitutive c-myc oncogene expression blocks mouse erythroleukaemia cell differentiation but not commitment, Nature 320 (1986), 760-763. doi:10.1038/320760a0

[43] K. Maruyama, S.C. Schiavi, W. Huse, G.L. Johnson and H.E. Ruley, myc and E1A oncogenes alter the responses of PC12 cells to nerve growth factor and block differentiation, Oncogene 1 (1987), 361-367.

[44] P.R. Amable, M.V.T. Teixeira, R.B.V. Carias, J.M. Granjeiro and R. Borojevic, Mesenchymal stromal cell proliferation, gene expression and protein production in human platelet-rich plasma-supplemented media, PLoS One (2014), 9. doi:10.1371/journal.pone.0104662

[45] S. Kushida, N. Kakudo, N. Morimoto, T. Hara, T. Ogawa, T. Mitsui, et al., Platelet and growth factor concentrations in activated platelet-rich plasma: A comparison of seven commercial separation systems, J Artif Organs 17 (2014), 186-192. doi:10.1007/s10047-014-0761-5

[46] J. Alsousou, M. Thompson, P. Hulley, A. Noble and K. Willett, The biology of platelet-rich plasma and its application in trauma and orthopaedic surgery - a review of the literature, Journal of Bone \& Joint Surgery, British Volume 91 (2009), 987-996.

[47] S. Braune, M. Walter, F. Schulze, A. Lendlein and F. Jung, Changes in platelet morphology and function during 24 hours of storage, Clin Hemorheol Microcirc 58 (2014), 159-170. doi:10.3233/CH-141876 